Dirce Mary Correia Lima Meisel

\title{
Integrina beta1 no desenvolvimento das glândulas salivares humanas
}

Tese apresentada à Faculdade de Medicina

da Universidade de São Paulo para obtenção do título de Doutor em Ciências.

Área de Concentração em Dermatologia

Orientadora: Profa. Dra. Silvia Vanessa Lourenço 
Dados Internacionais de Catalogação na Publicação (CIP)

Preparada pela Biblioteca da

Faculdade de Medicina da Universidade de São Paulo

Creprodução autorizada pelo autor

\section{Meisel, Dirce Mary Correia Lima}

Integrina beta-1 no desenvolvimento das glândulas salivares humanas / Dirce

Mary Correia Lima Meisel. -- São Paulo, 2010.

Tese(doutorado)--Faculdade de Medicina da Universidade de São Paulo.

Programa de Dermatologia.

Orientadora: Silvia Vanessa Lourenço.

Descritores: 1.Glândulas salivares 2.Antígenos CD29 3.Desenvolvimento fetal

USP/FM/DBD-474/10 


\section{DEDICATÓRIA}


Dedicatória

À DEUS.

À memória de meu pai, José.

À minha mãe, Dirce.

Aos meus irmãos: José Mario, Carlos Alberto, Paulo César.

Aos meus filhos: Gustavo e Renato.

O meu amor incondicional. 
AGRADECIMENTOS 
Agradecimentos

À minha orientadora, Profa Dra Sílvia Vanessa Lourenço, pelos méritos científicos, que estão além dos meus elogios, pelos muitos e preciosos ensinamentos, pela pessoa especial que DEUS colocou em minha vida, minha eterna gratidão.

Aos Professores e Doutores Pedro Paulo Chieffi e Ronaldo Griensk, por permitirem a realização deste trabalho.

Ao Prof. Dr. Thales de Brito pelo exemplo de pesquisador, pelas lições de vida acadêmica e a opurtunidade de iniciar meus conhecimentos em imunoistoquímica e hibridização in situ.

À Ana Maria Gonçalves Silva pelos incontáveis ensinamentos e orientação em todo meu aprendizado de imunoistoquímica e hibridização in situ, minha eterna gratidão.

Ao Prof. Dr. Luiz Caetano da Silva que permitiu o meu ingresso no Instituto de Medicina Tropical de São Paulo, como estagiária, ainda estudante do curso de Biomedicina.

À Profa Dra Hermínia Kanamura Kawada que tanto me ensinou quando decidi fazer meu trabalho de conclusão de curso no Instituto de Medicina Tropical de São Paulo.

À Clarice Pires Abrantes Lemos, amiga em todos os momentos desde os tempos de estagiária até hoje.

Sou particularmente grata à Maria Cristina Conceição Melo pela nossa grande amizade e por estar sempre disposta a me ajudar.

À Kátia Maria de Oliveira por sua disponibilidade e ensinamentos em informática em todos os momentos.

À pesquisadora Fabiana Martins de Paula por suas preciosas sugestões.

Aos queridos alunos e amigos: Sabrina Hitomi Uyekita, Ricardo Hsieh, Leonardo Kamibeppu e Flávia Marinho pelo convívio diário e por me ensinarem a ser uma pessoa mais feliz.

À bibliotecária Sônia Pedrozo Gomes pelas correções das referências bibliográficas, por todos esses anos de convívio. 
À Susana Velasco por todos esses anos de convívio.

À Maria de Fátima Valentin por facilitar o meu trabalho.

À Dona Eli Maria por sua eficiência e dedicação aos alunos da pós graduação .

À Maria Cristina Nakle pela amizade e tantos anos de convivência.

À D. Joana Maria D`Arc de Jesus e Adyles de Miranda pelo convívio diário. 
Esta tese está de acordo com as seguintes normas, em vigor no momento desta publicação:

Referências: sistema autor-data; adaptado de International Committee of Medical Journals Editors (Vancouver)

Universidade de São Paulo. Faculdade de Medicina. Serviço de Biblioteca e Documentação. Guia de apresentação de dissertações, teses e monografias. Elaborado por Anneliese Carneiro da Cunha, Maria Julia de A. L. Freddi, Maria F. Crestana, Marinalva de Souza Aragão, Suely Campos Cardoso, Valéria Vilhena. 2ª ed. São Paulo: Serviço de Biblioteca e Documentação; 2005.

Abreviaturas dos títulos dos periódicos de acordo com List of Journals Indexed in Index Medicus. 
SUMÁRIO 


\section{SUMÁRIO}

Lista de abreviaturas

Lista de símbolos

Lista de figuras

Lista de tabelas

Resumo

Summary

1 INTRODUÇÃO

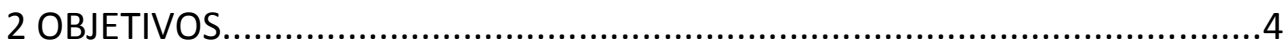

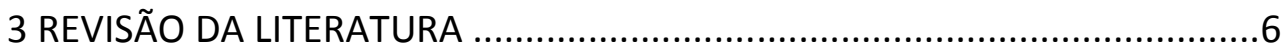

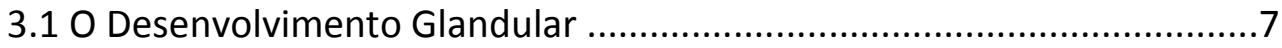

3.2 Interações Eptélio-Mesênquima ........................................................15

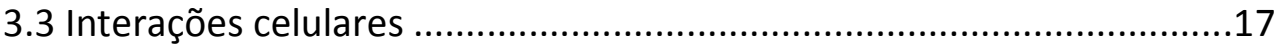

3.4 Integrinas e Transduções de Sinais ......................................................20

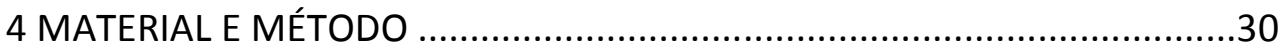

4.1 Obtenção e Seleção de fetos humanos para dissecção de estruturas

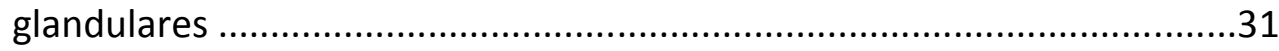

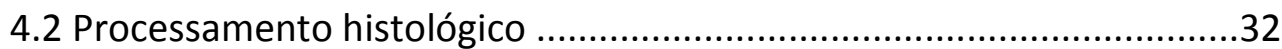

4.3 Hibridização in situ..........................................................................33

4.4 Protocolo utilizado nas reções de Hibridização in itu............................34

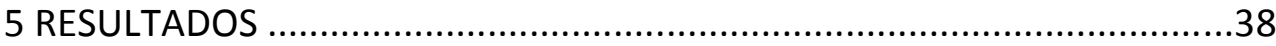

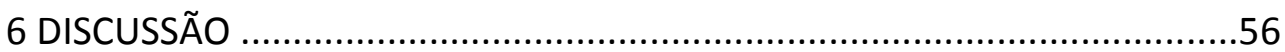


7 CONCLUSÕES.

8 REFERÊNCIAS .

9 APÊNDICE 
LISTAS 


\section{Lista de Abreviaturas}

G: gramas

ug: microgramas

$\mu \mathrm{m}$ : Micrômetros

mg: Miligramas

$\mathrm{mL}$ : mililitros

mM: Milimolar

BSA: Soro albumina bovina

Cdc 42: "Cell division cycle"

CISH: Hibridização in situ com cromógeno

DAB 3,3: Diamino benzidine tetrahidrocloride

DNA: Ácido desoxirribonucleico

cDNA: Ácido desoxirribonucleico complementar

DEPC: Dietil pirocarbonato

EGF: Fator de crescimento eptelial

EDTA: Ethylenediamine Tetraacetic Acid

EGFR: Receptor de fator de crescimento eptelial

FAK: Kinase de adesão focal

FGF: Fator de crescimento de fibroblasto

H/E: Hematoxilina/Eosina

HRP: Horseradish peroxidase

ICAP: "Integrin cytoplasmic domain-associated protein" 
$\mathrm{NaCl}$ : Cloreto de Sódio

PAS: Ácido periódico de Schiff

PBS: Solução salina tamponada com fosfatos

PCR: Reação em cadeia polimerase

PDGF: Fator de crescimento derivado de plaqueta

pH: Potencial hidrogeniônico

mRNA: Ácido ribonucléico mensageiro

RhoA :" Ras homolog, member A"

Rho GTPases: Família de pequenas proteínas sinalizadora G proteínas

SSC: Solução salina com citrato

TEA: Trietanolamine

TE:Tampão Tris-EDTA

VIU: Vida intra uterina 
Lista de Símbolos

$\alpha$ : Alfa

$\beta$ : Beta

ㄷ: Graus Celsius

$\%$ : porcentagem

$\mathrm{X}$ : vezes 
LISTA DE FIGURAS

FIGURA 1. Aspectos da anatomia da glândula salivar

FIGURA 1A. Representação esquemática da anatomia da glândula salivar

FIGURA1B a 1D: Em B, lóbulo de glândula salivar mucosa (H/E, aumento original X100). Em C, detalhes dos aspectos histológicos da estrutura glandular: ácino mucoso (asterisco) circundado por células mioepiteliais (seta azul) e ductos intra-lobulares (setas pretas) (H/E, aumento original X400). Em D e E: periferia de lóbulos de glândulas salivares mucosas com ácinos mucosos e ductos excretores inter-lobulares (setas) (H/E, aumento original X400).

FIGURA 2 . Exemplos de estruturas anatômicas que apresentam estruturas de glândulas salivares em desenvolvimento

FIGURA 3. Estágios de diferênciação das glândulas salivares

FIGURA 4. Expressão da integrina $\beta 1$ no desenvolvimento das glândulas salivares humanas (HIBRIDIZAÇÃO IN SITU)

FIGURA 5. Expressão da integrina $\beta 1$ no desenvolvimento das glândulas salivares humanas (HIBRIDIZAÇÃO IN SITU) 


\section{LISTA DE TABELAS}

Tabela 1 - Análise semi-quantitativa da expressão da integrina $\beta 1$ durante as diferentes fases morfogênese das glândulas salivares humanas e na glândula salivar plenamente desenvolvida (fase adulta) verificada pela técnica de hibridização in situ.

Tabela2- Expressão da integrina beta-1 durante as diferentes fases morfogênese das glândulas salivares humanas: análise comparativa da sensibilidade de detecção da proteínas pelas técnicas imunistoquímica e hibridização in situ 
RESUMO 
Meisel DMC. Integrina beta-1 no desenvolvimento das glândulas salivares humanas[tese]. São Paulo: Faculdade de Medicina, Universidade de São Paulo; 2010. 80p.

INTRODUÇÃO: O desenvolvimento das glândulas salivares envolve um processo coordenado de interações moleculares complexas, nas quais as integrinas têm papel fundamental. As integrinas são uma família de receptores transmembrânicos, heterodímeros, compostos por duas subunidades: alfa e beta que estão ligadas de forma não covalente e dependentes de cations bivalentes. Estes heterodímeros medeiam sinais intra e extracelulares envolvidos na organização das células em tecidos e órgãos durante seu desenvolvimento. Em particular a integrina beta-1 está envolvida na proliferação e diferenciação de células no desenvolvimento dos tecidos epiteliais. OBJETIVOS: Para compreender o papel da integrina beta-1 no desenvolvimento das glândulas salivares humanas, estudamos a sua expressão por meio da hibridização in situ em tecido fetal humano em desenvolvimento. MATERIAL E MÉTODOS: A hibridização in situ com o método chromogenic in situ hibridization (CISH) foi utilizada para investigar a expressão genética da integrina beta-1 em espécimes de glândulas salivares em desenvolvimento derivados de 30 fetos humanos em vários estágios gestacionais (de 8-25 semanas de vida intrauterina). Os resultados obtidos com a hibridização in situ foram relacionados com os aspectos morfológicos das glândulas salivares em desenvolvimento em cada fase da 
evolução da morfogênese glandular, por meio de análise qualitativa. RESULTADOS: Expressão da integrina beta-1 foi detectada em raras células na fase pre-botão. A expressão dessa molécula foi detectada em mais estruturas com a evolução do desenvolvimento morfogenético das glândulas salivares. CONCLUSÕES: A expressão a integrina beta-1 parece ser regulada de forma temporo-espacial e é associada ao estabelecimento do fenótipo maduro das glândulas salivares.

Descritores: 1.Glândulas salivares 2.Antígenos CD29 3.Desenvolvimento fetal 
SUMMARY 
Meisel DMCL. Integrin beta-1 in developing human salivary glands [thesis].São Paulo: Faculdade de Medicina, Universidade de São Paulo; 2009.

INTRODUCTION: Salivary gland development entails co-ordinated processes involving complex molecular interactions in which integrins have a fundamental role. The integrins are a family of heterodimeric transmembrane receptors comprising alpha and beta subunits that mediate intercellular and extracellular signals involved in the organisation of cells in tissues and organs during development. The beta- 1 integrin in particular have been implicated in proliferation and differentiation of cells involved in the development of epithelial tissues. OBJECTIVE: To understand the role of beta-1 integrin in salivary gland development we have studied its expression in human foetal tissues. MATERIAL AND METHODS: In situ hybridisation CISH technique was used to compare the expression and localisation of integrin beta- 1 with differentiation markers in developing human salivary glands obtained from foetuses of 8-25 gestational weeks. RESULTS: Integrin beta-1 first appeared during bud stage in a few cells and its distribution increased as salivary gland morphogenesis progressed. CONCLUSIONS: The developmentally regulated expression of integrin beta- 1 in association with the establishment of a mature phenotype of salivary glands is suggestive of its role in salivary gland morphogenesis.

Descriptors: 1. Salivary glands 2. Antigens CD29 3 . Fetal development 


\section{INTRODUÇÃO}

Os aspectos da biologia básica têm sido relevantes no estudo das condições fisiológicas, patológicas, e do desenvolvimento de diversos tecidos e órgãos. Ao longo das últimas décadas inúmeros estudos vêm sendo desenvolvidos para aprofundar nossos conhecimentos da histogênese das glândulas salivares. Várias teorias foram apresentadas na tentativa de determinar a gênese dos tumores das glândulas salivares, estabelecendo a relação entre a diferenciação das células neoplásicas com o desenvolvimento do segmento glandular e sua possível origem. (Dardick et al., 1990; Batsaskis et al., 1989). No entanto, poucos trabalhos se dedicam à análise do desenvolvimento e da diferenciação das glândulas salivares humanas, determinando uma relação morfológica e funcional com as neoplasias (Gustafsson et al., 1988).

Um dos aspectos importantes no desenvolvimento das glândulas salivares é a interação epitélio-mesênquima, que provavelmente tem efeito sinalizador na diferenciação final destas glândulas. As principais moléculas destas interações são as integrinas. Estas moléculas, além do seu importante papel na adesão celular, são responsáveis pela sinalização bidirecional através da membrana plasmática. Esses eventos de adesão e sinalização são dependentes de interações citoplasmáticas incluindo moléculas adaptadoras do citoesqueleto tais como talina e vinculina, quinases de adesão focal (FAK) e família Rho de GTPases. As cascatas de sinalização das integrinas, muitas vezes em cooperação com receptores de fatôres de 
crescimento, regulam e dirigem a migração, divisão e diferenciação celular (Meighan e Schwarzbauer, 2008). Além disso, as integrinas parecem estar relacionadas à manutenção, a regulação da renovação e proliferação das células tronco em seu nicho e mecanismos de apoptose (Watt e Hogan, 2000; Tanentzapf et al, 2007; Raymond et al, 2009; Ellis e Tanentzapf, 2010).

Assim, integrinas são importantes desde os estágios iniciais do desenvolvimento até a manutenção de tecidos adultos (Fassler e Meyer, 1995).

O envolvimento das integrinas no desenvolvimento de tecidos e órgãos e com a manutenção das células-tronco, tem atualmente se tornado relevante frente às intensas pesquisas sobre a possível utilização dessas células como forma terapêutica.

O presente estudo tem como objetivo investigar a possível participação da integrina beta-1 ( $\boldsymbol{\beta} 1)$, que é uma das principais subunidades da família das integrinas durante o desenvolvimento das glândulas salivares humanas, relacionando sua presença com os estágios da morfogênese glandular. 
2 OBJETIVOS 


\section{OBJETIVOS}

Considerando a importância das integrinas na biologia de diversos órgãos, nosso estudo pretende responder a seguinte questão:

As integrinas, em especial, a subunidade $\beta 1$, têm participação no processo de morfogênese das glândulas salivares humanas?

Para responder a esta questão, o presente trabalho terá os seguintes objetivos:

\subsection{Objetivos gerais}

Investigar a expressão genética da integrina $\beta 1$ em espécimes de glândulas salivares em desenvolvimento, derivados de fetos humanos nos vários estágios gestacionais (4 a 25 semanas de vida intra-uterina).

\subsection{Objetivos específicos}

2.2.1. Estudar a expressão genética da integrina $\beta 1$, demonstrada por meio da técnica de hibridização in situ;

2.2.2. Relacionar a expressão da integrina $\beta 1$ com a estrutura morfológica das glândulas em desenvolvimento em cada fase da morfogênese glandular. 
3 REVISÃO DA LITERATURA 


\section{REVISÃO DA LITERATURA}

\subsection{0 desenvolvimento glandular}

Todas as glândulas salivares se desenvolvem de forma similar, ou seja, originam-se a partir do epitélio bucal no início da vida fetal.

A glândula parótida humana inicia seu desenvolvimento entre a quarta e sexta semanas de vida intrauterina, nas dobras laterais do estomodeu. Por sua vez, a glândula submandibular origina-se do soalho bucal durante a sexta semana, enquanto que a sublingual se forma lateralmente, ao primórdio da glândula submandibular, entre a sétima e oitava semanas de vida intrauterina. Todas as glândulas salivares menores formam-se posteriormente, a partir do epitélio de revestimento de áreas específicas da cavidade bucal (Hand, 1986; Tongue e Luke,1994; Dale, 1994; Ellis e Auclair, 1996).

Pode-se definir o processo de morfogênese das glândulas salivares como sendo as fases que levam ao arranjo lobulado, típico deste tecido, enquanto que a diferenciação abrange os processos de ampliação da síntese e armazenamento dos grânulos de secreção. A citodiferenciação é, então, a combinação destes dois processos. Estudos sugerem que a morfogênese e a citodiferenciação das glândulas salivares estão parcialmente ligadas, mas são reguladas por processos distintos, 
sendo que a expressão total de um dos dois processos é modulada ou controlada pela matriz extracelular (Cutler,1990; Sakai et al., 2003 ).

Tucker, em 2007, divide o desenvolvimento das glândulas salivares em cinco estágios:

O primeiro estágio - pré-botão - abrange a indução da proliferação do epitélio de superfície pelo mesênquima adjacente, resultando no espessamento e formação dos botões epiteliais. O botão em crescimento é separado do mesênquima condensado pela lâmina basal secretada pelo próprio epitélio (Bernfield et al., 1972; Hand, 1986; Hiatt e Sauk, 1991; Klein, 1994; Elis e Auclair, 1996; Tucker, 2007).

O segundo estágio - botão inicial - caracteriza-se pela formação e crescimento dos cordões epiteliais principais. Neste estágio, observa-se a proliferação das células dos botões formando cordões celulares sólidos, constituídos por duas camadas de células, associados à condensação e à proliferação do mesênquima adjacente.

Ultraestruturalmente, as células indiferenciadas que compõem os cordões são caracterizadas como células cubóides irregulares, contendo numerosos ribossomos livres, nucléolos proeminentes, complexos de Golgi e retículo endoplasmático rugoso pouco desenvolvidos (Bernfield et al., 1972; Cutler, 1990; Tucker, 2007). 
Adi e colaboradores (1984) observaram que as células epiteliais presentes na formação dos cordões sólidos de glândulas submandibulares humanas apresentam material PAS (Periodic Acid Schiff) positivo no seu interior, indicando uma já possível produção de grânulos de material mucóide.

O terceiro estágio - pseudoglandular - compreende a ramificação da porção terminal dos cordões epiteliais e a continuação da diferenciação glandular. Ainda neste estágio, os cordões epiteliais se proliferam rapidamente e se ramificam formando bulbos terminais compostos por 10 a 12 células (Tucker, 2007).

No quarto estágio - canalicular - ocorrem repetidas ramificações dos cordões epiteliais nas porções terminais, formando os lóbulos compostos por um sistema de bulbos ramificados como uma árvore - processo de arborização. Neste estágio, a cápsula da glândula começa a se formar a partir do mesênquima e circunscreve o parênquima glandular (Bernfield et al., 1972; Cutler, 1990). Observase ainda a canalização dos cordões epiteliais, com a formação de um orifício criando um tubo ou ducto.

Estudos experimentais indicaram duas teorias a respeito do mecanismo de canalização: (1) graus diferentes de proliferação entre camadas externas e internas dos cordões epiteliais, (2) secreção do fluido pelas células ductais, provocando o aumento da pressão hidrostática e produzindo um lúmen junto ao cordão. Neste estágio do desenvolvimento observa-se a continuidade dos processos de ramificação das estruturas ductais e o crescimento dos septos do tecido conjuntivo que separam as glândulas salivares em lóbulos (Tucker, 2007). 
Acredita-se que a citodiferenciação dos tipos celulares específicos das glândulas salivares inicia-se após o estabelecimento das características de arborização. Define-se aqui, então, o quinto estágio - botão terminal - (Cutler, 1990; Tucker, 2007), caracterizado pela diferenciação morfológica das glândulas salivares em desenvolvimento. Neste estágio, a atividade mitótica, ao invés de ocorrer em todo o cordão epitelial, ocorrerá apenas na porção terminal do bulbo, onde as células irão se diferenciar em células dos túbulos terminais e pró-acinares.

Com a formação dos lúmens nos bulbos terminais, ocorrem fissuras nas células circunjacentes dividindo cada bulbo terminal em várias subunidades constituídas por duas camadas de células circundando um lúmen e que são chamados de túbulos terminais. Visto que as unidades da porção terminal luminal encontram-se diferenciadas, não podemos chamá-las de ácinos, sendo denominadas, preferivelmente, "sacos terminais". Acredita-se que as células externas originem as mioepiteliais e basais, enquanto que as internas sofrem diferenciação, formando células acinares e luminais (Klein, 1994; Ellis e Auclair, 1996).

As células mioepteliais se desenvolvem simultaneamente à citodiferenciação das acinares e caracterizam-se pela agregação de microfilamentos e pela presença de actina, miosina, e filamentos intermediários de pré-queratina, como pode ser demonstrado pela imunoistoquímica (Yaku, 1983; Klein, 1994).

A maturação das células acinares ocorre de maneira diferente para ácinos mucosos e serosos, cujos estágios são classificados de acordo com a morfologia dos 
grânulos de secreção e das organelas celulares. O aumento da dilatação das cisternas do retículo endoplasmático rugoso pelas proteínas secretoras caracteriza o primeiro sinal de diferenciação dos sacos terminais em ácinos. Posteriormente, observa-se a presença de grânulos secretores agranulados e Complexo de Golgi funcional. As quantidades de retículo endoplasmático rugoso, Complexo de Golgi e grânulos secretores aumentam gradualmente com a maturação dos ácinos (Yaku , 1983; Klein, 1994).

A diferenciação dos ductos excretores das glândulas salivares ocorre a partir dos cordões principais. As ramificações distais dos cordões principais originam os grandes ductos estriados, enquanto que as células dos túbulos terminais dão origem aos ductos intercalares, aos pequenos ductos estriados, às células secretoras e às mioepteliais. Somente após a canalização dos cordões celulares sólidos observa-se a diferenciação dos ductos estriados maiores e dos ductos excretores (Denny et al., 1997).

A continuação e maturação da citodiferenciação ocorrem devido a estímulos provenientes dos mecanismos secretores e da inervação da glândula salivar. Entretanto, a formação completa da glândula ocorrerá apenas no período pós-natal, e está relacionada com (1) a maturação do estímulo de secreção, responsável pela ativação dos receptores de membrana que sinalizam caminhos de transdução de sinal junto à célula e controlam a secreção das células; e com (2) o estabelecimento de conexões neurais do sistema nervoso autônomo, que é o primeiro regulador da função das glândulas salivares (Hand, 1986; Klein, 1984; Ellis e Auclair, 1996). 
Este processo de desenvolvimento e maturação faz com que as glândulas salivares adquiram a forma de estrutura composta túbulo-acinar, indicando a presença de um sistema ductal ramificado e unidades secretoras com porção tubular e acinar. Estas glândulas são exócrinas, cujas secreções fluem para o interior da cavidade bucal.

As glândulas salivares possuem, histologicamente, três tipos de porções secretoras: mucosas, serosas e mistas; e três tipos de ductos: intercalados, estriados - intralobulares - e excretores - interlobulares. As principais células encontradas são: mucosas, serosas e mioepiteliais. Uma cápsula de tecido conjuntivo denso, que se dispõe ao redor da glândula formando septos e dividindo o parênquima em lóbulos, circunda e fornece suporte para os sistemas ductais e secretores. O tecido conjuntivo é importante para a sustentação tanto das glândulas como dos nervos (autônomos), vasos sanguíneos e linfáticos (Bhaskar, 1978; Hand, 1986; Klein, 1994; Tongue e Luke, 1984; Ellis e Auclair, 1996).

Após sua formação total, as glândulas salivares classificam-se como (1) glândulas maiores, que compõem todo o conjunto de parótida, sublingual e submandibular e (2) glândulas menores, que são nomeadas de acordo com sua localização, como labiais, bucais, linguais, palatinas, gengivais e glossopalatinas (Bhaskar, 1978; Hand, 1986; Klein,1994). O exemplo gráfico da estrutura de uma glândula salivar completamente diferenciada pode ser observado na Figura 1. 


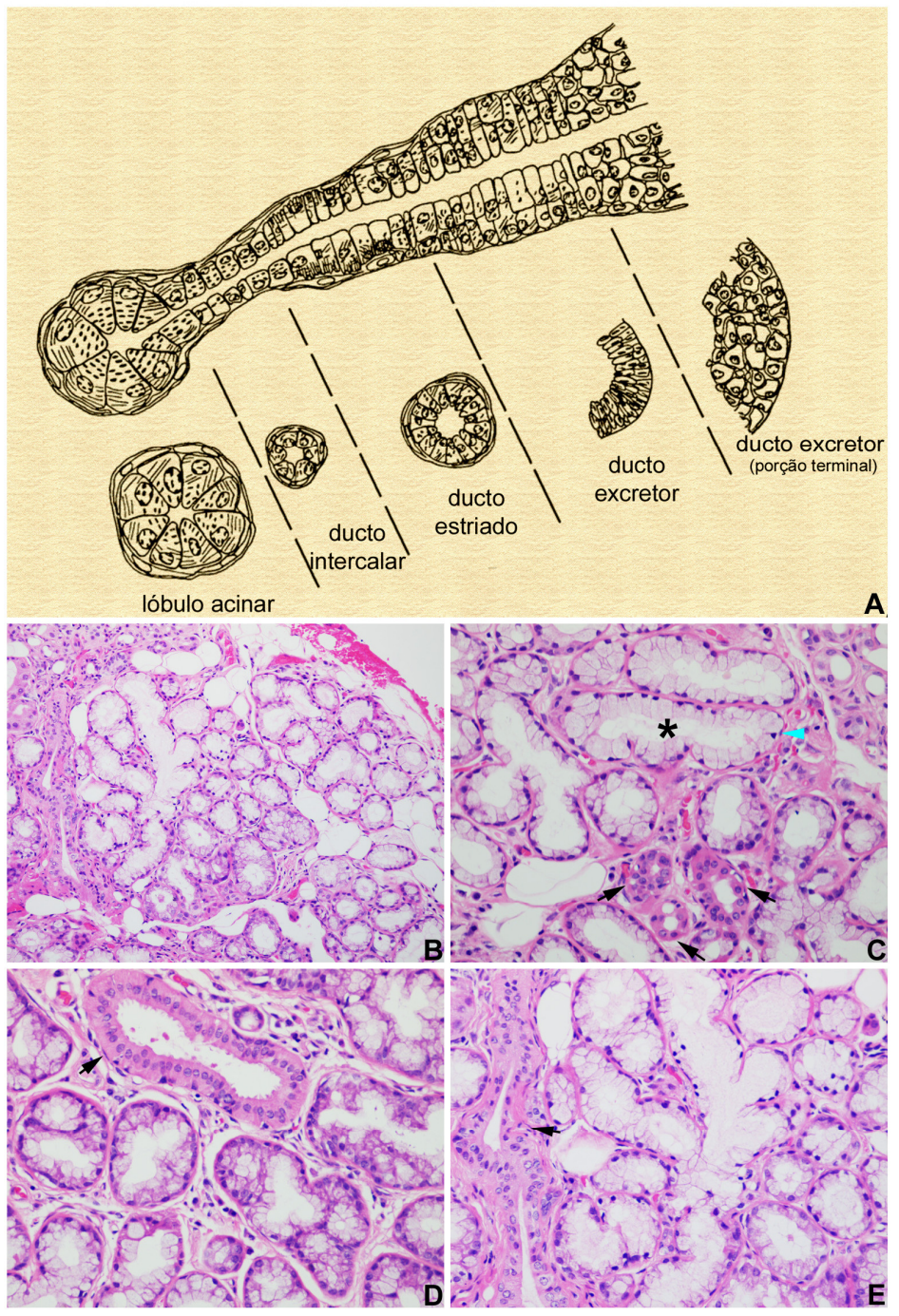

FIGURA 1

Aspectos da anatomia e histologia da glândula salivar mucosa

1A: Representação esquemática da anatomia da glândula salivar.

1B a 1D: Em B, lóbulo de glândula salivar mucosa (H/E, aumento original X100). Em C, detalhes dos aspectos histológicos da estrutura glandular: ácino mucoso (asterisco) circundado por células mioepiteliais (seta azul) e ductos intra-lobulares (setas pretas) (H/E, aumento original $\mathrm{X} 400)$. Em D e E: periferia de lóbulos de glândulas salivares mucosas com ácinos mucosos e ductos excretores interlobulares (setas) (H/E, aumento original X400). 
A formação das glândulas salivares, como a de outros órgãos, envolve um mecanismo morfogenético de coordenação, incluindo mudanças reguladas que influem na forma celular, na expressão de genes; e na migração celular direcionada, levando a um completo desenvolvimento glandular com importantes funções secretoras. Embora o desenvolvimento local e temporal seja significativamente diferente entre as diversas glândulas, o processo de desenvolvimento é similar e sofre influências de fatores intrínsecos e extrínsecos que regulam o processo de morfogênese, proliferação e diferenciação celular.

Os fatores intrínsecos são definidos como características pré-progamadas da expressão genética específica para cada tipo celular. Durante sequência programada, os genes são ativados e desativados em tempos apropriados levando ao crescimento e diferenciação normal das células (Cutler, 1990; Klein, 1994; Denny, et al, 1997). Os fatores extrínsecos são sinais produzidos pela interação célula-célula e célula-matriz-extracelular. O desenvolvimento do tecido glandular envolve, portanto, interações entre o epitélio e o mesênquima para formar a porção funcional da glândula (parênquima). Estas interações são definidas como induções secundárias, nas quais a presença do mesênquima torna-se indispensável para o desenvolvimento normal do epitélio.

O mesênquima, também chamado de ectomesênquima ou mesoectoderma, é formado por células derivadas do mesoderma e da crista neural. Consequentemente, o ectomesênquima desempenha um papel fundamental no desenvolvimento do tecido glandular humano, uma vez que sua interação com o 
epitélio regula tanto a iniciação como o crescimento e a citodiferenciação das células do tecido glandular (Hand, 1986; Azuma e Sato, 1994; Klein, 1994; Denny et al, 1997; Sakai et al; 2003).

A atividade coordenada de um grupo de células primitivas, que interagem entre si e com as células vizinhas, determina a posição e a forma dos órgãos. Embora não tenhamos informações suficientes sobre a coordenação destas atividades, sabemos que a expressão de ligantes e receptores específicos de superfície celular estão altamente relacionados em uma rede complexa de sinalização, que regula os processos de divisão, migração e diferenciação celulares (Thiery, 2003).

\subsection{Interações eptélio-mesênquima}

O padrão específico de ramificação de diferentes glândulas e o grau de suas diferentes secreções parecem ser controlados por sinais do mesênquima. 0 primeiro trabalho para se identificar o importante papel da sinalização epitéliomesênquima foi realizado por Borghese (1950) com estudos da cápsula do tecido conjuntivo na regulação do desenvolvimento da glândula submandibular de camundongos. Ele notou, em sistemas in vitro de cultivo celular, que rudimentos de glândula submandibular de camundongos, os quais tinham sido removido o mesênquima capsular, não sofriam o processo completo de morfogênese, ramificação ou crescimento. 
Grobstein (1953a) confirmou os achados de Borghese e demonstrou que as interações epitélio-mesênquima eram importantes desde as fases iniciais do desenvolvimento. Ainda em $1953 b$ sugeriu que a indução da ramificação na morfogênese parecia ser dependente de macromoléculas produzidas pelo mesênquima.

Estudos subsequentes realizados por Kallman e Grobstein (1966) sugeriram que tais moléculas representavam o colágeno. Spooner and Faubion (1980) forneceram dados indicando que a síntese e deposição de colágeno I e III é necessária para morfogênese e ramificação das glândulas salivares. Posteriormente, Kadoya e Yamashina (1993) demonstraram a presença da integrina (subunidade a6), receptor de laminina, na superfície basal do epitélio da glândula submandibular. Kadoya et al (1995 e 2003) demonstraram também que laminina e subunidades $\alpha 6$ e $\beta 1$ são necessárias na morfogênese/ramificação das glândulas salivares.

Kashimata e Gresik (1997) demonstraram que além de moléculas da matriz extracelular, fatores de crescimento como o fator de crescimento epidérmico (EGF) são fisiologicamente importantes neste processo, uma vez que o RNA mensageiro para EGF e o receptor EGFR são expressos durante o desenvolvimento fetal da glândula submandibular e induzem a síntese da subunidade $\alpha 6$ da integrina.

Atualmente, pesquisadores relatam a importância de moléculas que intermedeiam a comunicação entre parênquima e mesênquima. Essas moléculas são principalmente representadas por diversas famílias de moléculas de adesão, das 
quais as integrinas se destacam (Hynes, 1992; Larsen et al, 2006; de Archangelis e Georges-Labouesse, 2000). Nesse âmbito, em que a matriz extracelular é constituída por uma variedade de proteínas especializadas e proteoglicanas capazes de regular diversos processos celulares como proliferação, diferenciação e migração, sabe-se que o controle da adesão exercido pelas integrinas é de fundamental importância (Yilmaz e Christofori, 2009).

\subsection{As interações celulares}

Interações celulares são essenciais na manutenção da homeostase e particularmente importantes durante o desenvolvimento de organismos multicelulares. A partir dos estágios mais precoces do desenvolvimento, as células estabelecem relações com a matriz extracelular, e estas constituem um dos principais pré-requisitos para a diferenciação celular e organização tecidual (De Arcangelis e Georges- Labouesse, 2000). De forma geral, as unidades funcionais da adesão celular são tipicamente constituídas de complexos multiproteicos formados por moléculas de adesão, componentes da matriz extracelular e placas intracitoplasmáticas (Gumbiner, 1996; Streuli e Akhtar, 2009).

As integrinas constituem a principal família de moléculas que intermedeiam interações entre células e matriz extracelular, influenciando direta ou indiretamente numerosos aspectos do comportamento celular - adesão e migração, proliferação, diferenciação. Ainda, essas moléculas têm sido 
crescentemente relacionadas com a manutenção de células-tronco/multipotentes em seu nicho, definindo sua renovação e/ou sua diferenciação terminal (De Arcangelis e Georges-Labouesse, 2000; Taneentzapf et al., 2007; Ellis eTaneentzap, 2010)

O termo integrina foi introduzido em 1987 por Hynes e colaboradores para descrever uma família de proteínas transmembrânicas que parecia ser componente fundamental e integral da membrana celular, ligando o citoesqueleto à matriz extracelular.

Essas moléculas são heterodímeros transmembrânicos, considerados receptores da membrana celular, compostos por duas subunidades $\alpha$ (alfa) e $\beta$ (beta) que estão ligadas de forma não-covalente e dependente de cátions bivalentes (Hynes, 1992). Mais de 20 heterodímeros de integrinas já foram identificados e estes reconhecem diferentes componentes da matriz extracelular, bem como outros ligantes do meio e da superfície de outras células, por meio de sua porção extracitoplasmática (Hynes, 1992; Beauvais-Jouneau e Thiery, 1997). Cada subunidade é composta de domínios extracitoplasmáticos grandes, de uma porção transmembrânica e de uma cauda citoplasmática curta, exceto a subunidade $\beta 4$.

As integrinas agrupam-se em áreas denominadas adesões focais, onde sua porção intracitoplasmática mantém contato com o citoesqueleto. Desta forma, as integrinas proporcionam um canal de comunicação entre o meio extracelular e intracelular, ativando e desativando vias de sinalização que influenciarão o 
comportamento celular (Giancotti e Ruoslahti, 1999; Luo et al., 2007; Gahmberg et al., 2009).

No meio extracelular, as integrinas servem primariamente como receptores de colágeno, laminina e fibronectina. Cada dímero de integrina reconhece mais de um ligante e, por sua vez, cada ligante pode se unir a diferentes tipos de integrinas. Entretanto cada interação é específica e ligantes diferentes ativarão vias distintas de sinalização no meio intracelular (Heino, 2000).

No meio intracelular, o domínio citoplasmático das integrinas interage com as proteínas do citoesqueleto - $\alpha$-actinina, talina, filamina, promovendo vias de transdução de sinais que envolvem proteínas relacionadas a diversas cascatas sinalizadoras (Hemler, 1998). Adicionalmente, o domínio citoplasmático das integrinas interage com as proteínas reguladoras, como por exemplo, paxilina, calreticulina, citoesinas, endonexinas e ICAP, que podem modificar a afinidade dessas moléculas pelos seus receptores extracelulares (Darribère et al., 2000).

Nesse complexo cenário da adesão celular, as integrinas participam de vias de sinalização que controlam a proliferação e sobrevivência celulares, a indução genética, a diferenciação e a mobilidade. Para realizar estas atividades biológicas, as integrinas são recrutadas para complexos intracelulares que contém numerosas proteínas e moléculas de sinalização (Hemler, 1998).

Mudanças no repertório de integrinas na superfície celular e na composição da matriz extracelular têm vastas consequências no comportamento celular, 
alterando seu estado funcional e desencadeando processos como proliferação, diferenciação, migração e morte (Yilmaz e Cristofori, 2009).

\subsection{Integrinas e transdução de sinais}

Uma variedade de mecanismos de adesão reafirma a importância da organização e comunicação celulares na arquitetura tecidual. Interações celulares estáveis são necessárias para a manutenção da integridade tecidual, e mudanças dinâmicas nesta adesão são importantes nos processos de morfogênese e diferenciação. Estes mecanismos são altamente regulados e intimamente relacionados aos processos de desenvolvimento, migração e morfo-diferenciação celulares (Giancotti e Ruoslahti, 1999; Guan e Chen, 1996; Streuli e Akhtar, 2009; Meighan e Schwarzbauer, 2008).

O controle da adesão celular ocorre em diferentes níveis, e inclui modulação da afinidade e interações coordenadas com o citoesqueleto de actina (Giancotti e Ruoslahti, 1999). Os sinais gerados localmente através dos receptores de adesão são envolvidos em meticulosos mecanismos de regulação. Vias de sinalização são ainda influenciadas por receptores de fatores de crescimento e fatores solúveis do meio. Sinais gerados localmente através da adesão celular também interagem com vias clássicas de transdução de sinais que ajudam a controlar o comportamento celular (Giancotti e Ruoslahti, 1999; Yilmaz e Christofori, 2009). 
A associação entre a adesão física e os mecanismos de sinalização celular integra os diversos aspectos da morfogênese, proliferação celular, diferenciação e coordenação, que são essenciais para a manutenção da vida (Giancotti e Ruoslahti, 1999; Guan e Chen, 1996).

As integrinas exercem papel fundamental nesse cenário, participando da transdução de sinais que controlam diversos mecanismos e processos fisiológicos e patológicos celulares. Sua capacidade de sinalização ocorre basicamente através de dois mecanismos chamados sinalização "inside out" e "outside in" que regulam as atividades proliferativas e de diferenciação de células dependentes de adesão (Hynes, 1992).

O mecanismo "inside out" é o fenômeno pelo qual a célula regula o estado de afinidade de suas integrinas. Este mecanismo parece estar relacionado com a propagação de mudanças conformacionais no sentido dos domínios citoplasmáticos das integrinas para seus epítopos de ligação extracitoplasmáticos, em resposta a eventos sinalizadores intracelulares. Evidências correlacionam estas mudanças conformacionais a eventos de fosforilação e desfosforilação, que permitem a associação de proteínas que podem regular o estado de ativação destes receptores (Hynes, 1992; Clark e Brugge, 1995; Jones e Walker, 1999; Gahmberg et al., 2009).

O mecanismo "outside in" medeia sinais originários da matriz extracelular após a ligação de integrinas com suas proteínas, e envolve a regulação de diversos processos celulares fundamentais, tais como a formação de adesões focais (Hynes, 1992; Clark e Brugge, 1995; Jones e Walker, 1999; Gahmberg et al., 2009). 
As integrinas, portanto, não funcionam como receptores isolados, mas engajadas em complexos supramoleculares nos locais de adesão celular à matriz (Juliano, 1996). Suas caudas citoplasmáticas são, em sua grande maioria, curtas, requerendo a presença de proteínas adaptativas que as conectem com o citoesqueleto, as proteínas quinases e os fatores de crescimento, uma vez que não há evidências da presença direta de enzimas no processo inicial de sinalização (Clark e Brugge, 1995).

Estudos realizados em receptores sintéticos ou mutantes de integrinas indicam que a subunidade $\beta$ é necessária e suficiente para ligar a molécula de integrina à adesão focal, enquanto que a subunidade $\alpha$ regula a especificidade das interações ligante-dependentes (Clark e Brugge, 1995). A interação das caudas citoplasmáticas das integrinas com as proteínas intermediadoras de sua ligação com o citoesqueleto de actina (talina, $\alpha$-actinina, paxilina, vinculina e tropomiosina) tem função integrante na estruturação da morfologia e mobilidade celulares, além de contribuir sobremaneira na associação de proteínas sinalizadoras que regulam a transdução de sinais, levando a mudanças comportamentais celulares induzidas por estes receptores (Juliano, 1996; Clark e Brugge, 1995).

Dessa forma, duas hipóteses tentam explicar os mecanismos básicos da sinalização proveniente da interação entre as integrinas e a matriz extracelular e seu controle sobre a expressão genética, tendo como consequência mudanças no comportamento celular. 
A primeira hipótese sugere que a ligação célula-matriz extracelular intermediada pelas integrinas inicia a reorganização do citoesqueleto, resultando em mudanças profundas na morfologia celular, o que influencia seu comportamento e eventualmente o seu padrão de expressão genética (Dannen e Sonnenberg, 2003).

A segunda hipótese enfatiza a função das integrinas como moléculas sinalizadoras, que excitam cascatas de sinalização, gerando mudanças na expressão genética (Dannen e Sonnenberg, 2003).

Entre os sinais gerados pela influência das integrinas destacam-se os aumentos do $\mathrm{pH}$ intracelular, o aumento do cálcio intracelular, a síntese de lipídeo inositol e a fosforilação de quinases associadas às adesões focais (Varner e Cheresh, 1996).

As vias sinalizadoras ativadas pelas integrinas foram identificadas através de análise dos eventos bioquímicos que são iniciados pela interação das integrinas com mensageiros secundários - proteínas constitutivas ou reguladas pela fosforilação de tirosinas - processo que tem significado ímpar na viabilização das adesões focais (Juliano, 1996; Clark e Brugge, 1995).

As cascatas de sinalização intermediadas pelas integrinas, também influenciarão a progressão do ciclo celular através da ativação de Jun, Fos e ciclinas, via Ras (Giancotti e Ruoslahti, 1999). A regulação positiva e negativa destas cascatas é mediada por fosfatases de tirosina (Giancotti e Ruoslahti, 1999). 
Adicionalmente, a interação das integrinas com receptores de fatores de crescimento tais como EGF, FGF, e PDGF, nos locais das adesões focais, resulta no aumento da fosforilação destes receptores, no acúmulo de substratos que irão fomentar sua afinidade e na avidez por agentes mitogênicos e de vias sinalização que influenciarão, por sua vez, o comportamento celular como proliferação, diferenciação e morte (Boudreau e Jones, 1999; Larsen et al., 2006).

A sinalização das integrinas ainda é essencial no controle do ciclo celular e sua evolução através das fases G0-G1 (Juliano, 1996). Durante a divisão celular, células dependentes de adesão perdem momentaneamente sua ancoragem, o que facilita a replicação. Em contraste, adesão celular a tipos específicos de matriz extracelular favorece a parada do ciclo, agindo em sinergismo com citocinas e outros fatores solúveis do meio, que orquestram juntamente com as integrinas os fenômenos de morfogênese e diferenciação celular (Giancotti e Ruoslahti, 1999; Yilmaz e Christofori, 2009).

A composição da matriz extracelular é essencial para a determinação do comportamento fenotípico de cada célula. O elo entre este estímulo externo e o meio interno é exercido primariamente pelas integrinas (Giancotti e Ruoslahti, 1999; Yilmaz e Christofori, 2009).

Os conhecimentos atuais sobre as vias de sinalização relacionadas às integrinas ainda são truncados e dependentes de aprofundamento. Dada à importância das integrinas e de sua participação em processos biológicos, estudos vêm sendo realizados no sentido de elucidar a distribuição e compreender as 
funções dessas moléculas também durante o desenvolvimento. As integrinas parecem estar intimamente ligadas a funções que regulam e que se relacionam aos processos de adesão celular, migração e morfo-diferenciação durante o desenvolvimento dos organismos celulares, bem como em suas vidas adultas (Giancotti e Ruoslahti, 1999).

Durante o desenvolvimento, as integrinas são expressas de forma dinâmica e regulada, e estudos in vitro mostraram que a interação célula-matriz extracelular mediada pelas integrinas é importante para a diferenciação de diversos tipos celulares tais como mioblastos, queratinócitos, células da crista neural, células epiteliais, células do músculo cardíaco, entre outras. Em especial, a subunidade $\beta 1$ exerce grande influência sobre o processo de diferenciação dessas células (Maitra et al., 2000; Green et al., 1998).

Na organogênese, as integrinas têm se mostrado importantes na formação do sistema nervoso central dos vertebrados participando de complexos eventos indutivos e rearranjos teciduais até a produção do tubo neural. A partir disto, a crista neural se forma e suas células migram ao longo da matriz extracelular rica em fibronectina, laminina, vitronectina, colágeno e tenascina (Darribère et al., 2000; Dufour et al., 1998).

Durante os processos de miogênese, importante expressão de integrinas tem sido relatada. Essa expressão é decrescente até a completa diferenciação muscular no embrião bem desenvolvido (Sastry et al., 1996). Na linha de estudos sobre o desenvolvimento do músculo cardíaco, relata-se que células-tronco 
embrionárias nulas para integrina $\beta 1$ têm sua diferenciação severamente alterada quando comparadas com células-tronco selvagens. Nesse estudo os autores concluem que a diferenciação do músculo cardíaco depende de forma crucial da presença da subunidade $\beta 1$ das integrinas, a despeito das outras subunidades $\alpha$ que possam associar-se a ela (Fässler et al., 1996).

Outro estudo ressalta, ainda, que a adesão da subunidade $\beta 1$ à matriz extracelular parece ser essencial para a ativação da ciclina D1 e sua cascata, durante o desenvolvimento do coração. O bloqueio desta subunidade inibe a progressão do ciclo celular de células embrionárias, sugerindo que a integrina $\beta 1$ pode agir como mecanotransdutor importante para a migração celular durante a morfogênese do músculo cardíaco (Maitra et al., 2000). A presença de integrinas ainda é citada nos processos de vasculogênese e angiogênese (Drake et al., 1995; Hammes et al., 1996).

A morfogênese tubular, que leva à formação da traquéia e bronquíolos distais durante o desenvolvimento fetal, também depende das interações entre as integrinas e matriz extracelular, sendo essas interações as responsáveis pela modulação da migração das células epiteliais nesse processo (Coraux et al., 2000).

Na mucosa gástrica em desenvolvimento, a expressão coordenada de integrinas $\alpha 2$ e $\alpha 3$ e a redistribuição celular da integrina $\alpha 2 \beta 1$ parecem representar evento-chave na diferenciação das glândulas secretoras, especialmente das células responsáveis pela síntese e secreção de enzimas digestivas (Chénard et al., 2000). 
O envolvimento das integrinas é relatado no controle da proliferação, apoptose, diferenciação e manutenção da polaridade baso-apical de células epiteliais mamárias e, portanto, essencial para o desenvolvimento e função da glândula mamária normal (Faraldo et al., 1998). Em trabalho mais recente, Faraldo e seus colaboradores verificaram que a alteração da função da integrina $\beta 1$ na glândula mamária de camundongos causa diminuição da proliferação de seu componente epitelial durante as fases de gestação e lactação, demonstrando ainda a relação desse fato com vias sinalizadoras que regulam tais processos por meio da subunidade $\beta 1$ (Faraldo et al., 2001).

Na última década, as integrinas, especialmente a subunidade $\beta 1$, vêm sendo relacionadas à presença de células-tronco e à manutenção destas células em seus nichos (Watt e Hoggan, 2000). Na pele, a população de células-tronco apresenta níveis altos de expressão de integrina $\beta 1$, e à medida que estas células tornam-se comprometidas com a diferenciação, observa-se queda nos níveis dessa proteína (Bagutti et al., 2001). Em outros trabalhos mais atuais, esta pesquisadora e seu grupo avançam no estudo da integrina $\beta 1$ em relação às células-tronco confirmando sua inter-relação e sugerindo que diferenças no agrupamento e mobilidade dessas células implicam em diferenças na adesividade celular, mantendo-as em seus nichos (Watt, 2001; Zhu et al., 1999; Bagutti et al., 2001). A diferença nos níveis de expressão da integrina $\beta 1$ em células-tronco e células multipotentes é fenômeno conhecido da diferenciação epitelial (Watt, 2002). 
A expressão da integrina $\beta 1$ na pele ainda relaciona-se diretamente com a manutenção deste tecido. A perda desta subunidade resulta em perda de pêlos, folículos pilosos aberrantes, diminuição significante da proliferação dos queratinócitos e anomalias na sua morfologia, organização e diferenciação. Relatam-se também distorções na formação da membrana basal e na patogênese de algumas doenças vésico-bolhosas (Brakebush et al., 2000).

Nas glândulas salivares, a identificação de células-tronco tem sido perseguida, no intuito de se compreender os processos de desenvolvimento e diferenciação dessas glândulas, bem como as neoplasias que as acometem. Entretanto, nas revisões disponíveis sobre o assunto, não há consenso sobre a localização do compartimento proliferativo ou das células-tronco na estrutura das glândulas salivares normais (Dardick e Burford-Masson, 1993). Sua identificação poderia abrir novas possibilidades de estudos na área de regeneração desse tecido, e as integrinas podem ser moléculas-chave na identificação dessas células.

Estudos sobre as integrinas nas glândulas salivares humanas são escassos e em sua maioria exploram a presença e distribuição dessas moléculas nas glândulas salivares normais e em neoplasias que as acometem (Sunardhi-Widyaputra e Vandamme, 1994; Franchi et al., 1997; Loducca et al., 2000; Lourenço e Lima, 2007). Estudo in vitro sobre a diferenciação de células cultivadas a partir de glândula submandibular de camundongos mostrou que a integrina $\alpha 3 \beta 1$ é necessária para a diferenciação de células glandulares e que sua falta compromete a função de 
componentes de complexos de adesão, bem como importantes vias de sinalização celular (Menko et al., 2001).

$\mathrm{Na}$ realidade das glândulas salivares, portanto, muitos processos do desenvolvimento e diferenciação ainda são amplamente desconhecidos, especialmente com relação à presença e localização de células-tronco, bem como a processos iniciais de comprometimento celular com a diferenciação. Sendo assim, baseados na literatura e em nossa própria experiência, acreditamos que a presença da subunidade $\beta 1$ pode desempenhar funções distintas em diferentes momentos da diferenciação glandular. Em fases mais precoces, essa subunidade parece estar relacionada à presença de possíveis células-tronco, e mais tardiamente, à diferenciação e função glandular.

Alicerçados nas informações da literatura supracitada que enfatiza a importância da subunidade $\beta 1$ das integrinas em diversos processos e fases do desenvolvimento de tecidos e órgãos e na manutenção de células-tronco em seus compartimentos, nos propomos a estudar a expressão genética da integrina $\beta 1$ em diferentes estágios do desenvolvimento das glândulas salivares humanas, no sentido de investigar a participação dessa molécula nos compartimentos proliferativos e células-tronco dessas glândulas. 


\section{MATERIAL E MÉTODO}

\subsection{Obtenção e seleção de fetos humanos para dissecção de estruturas glandulares.}

Trinta fetos humanos provenientes de abortos legais pesando até $500 \mathrm{G}$ e submetidos a exame de verificação de óbito foram utilizados em nosso estudo. Este material foi coletado na Divisão de Anatomia Patológica do Hospital das Clínicas da Faculdade de Medicina da Universidade de São Paulo. Espécimes macerados e em mau estado de preservação foram excluídos da amostra. Também foram descartados fetos que apresentavam aberrações ou que sabidamente possuíam algum tipo de alteração genética. As idades gestacionais dos fetos foram determinadas por meio da medida plantar segundo Mc Bride et al., 1984.

Estudo anatômico da face fetal foi realizado para haver maior precisão durante a dissecção com melhor aproveitamento das estruturas glandulares.

As estruturas orais e glandulares foram então dissecadas com instrumentos cirúrgicos com o intuito da máxima preservação das estruturas e órgãos, do ponto de vista anatômico e histopatológico. Todas as estruturas dissecadas foram então catalogadas de acordo com a idade fetal e localização anatômica ou órgão, e processadas histologicamente para posterior análise em microscopia óptica para identificação das estruturas glandulares e determinação de sua fase de desenvolvimento. 
Nos fetos em fase mais precoce de desenvolvimento, cuja anatomia facial ainda não permitia separação por estruturas, a dissecção se procedeu "en bloc", separando-se toda a porção inferior da face para processamento.

Em geral, foram dissecadas as seguintes estruturas:

- Glândulas parótidas

- Glândulas submandibulares

- Mucosa jugal

- Lábios - superior e inferior

- Palato

- Língua

- Soalho bucal

\subsection{Processamento histológico}

Todo o material dissecado foi processado histologicamente e posteriormente embebido em blocos de parafina. Cortes histológicos de $5 \mu \mathrm{m}$ de espessura foram realizados e estes foram corados com hematoxilina e eosina para checagem da presença e análise morfológica das estruturas glandulares.

Para facilidade da análise de nosso estudo, as estruturas glandulares encontradas foram classificadas de acordo com seu estágio de diferenciação, a saber: 
- Pré- Botão

- Botão Inicial

- Pseudoglandular

- Canalicular

- Botão Terminal

\subsection{Hibridização in situ}

Para a realização dessa técnica, foi utilizada sonda cDNA para integrina $\beta 1$. Estudo da sequência genética da integrina $\beta 1$ foi realizado in silico (http://www.ncbi.nlm.nih.gov/pubmed) a fim de podermos selecionar a melhor sequência a ser utilizada em nossa sonda. Para a realização dessa técnica, foi utilizada sonda cDNA para integrina $\beta 1$. A fim de selecionarmos a melhor sequência a ser utilizada em nossa sonda, realizamos estudo da sequência genética in silico). 0 desenho das sondas foi orientado pelo Departamento de Patologia Bucal do St Bart's and The Royal London School of Medicine and Dentistry, Londres, Inglaterra. Dessa forma, três sondas de integrina $\beta 1$ foram sintetizadas com sequências diferentes, e após testes, foi escolhida apenas uma com a qual realizamos todos os experimentos e cuja especificação encontra-se a seguir:

\section{5'-3' AAA TTC CTG AGC TTA GCT GGT GTT GTG CTA ATG TSS GGC ATC ACA GTC TTT} TCC ACA AAT (GeneBank X07979) - sonda sensede cDNA, marcada com biotina e complementar às sequências utilizadas para reação da polimerase em cadeia (PCR). 
Sonda "scramble", marcada com biotina foi empregada seguindo o mesmo protocolo e foi considerada como controle negativo (5'-3' CCG TGT GGG ACG GAA CTT ACG CGA TSS CGG CAG ACT AAT AGC AGT CGG AAG GTC CAT).

\subsection{Protocolo utilizado nas reações de hibridização in situ}

Fragmentos de $5 \mu \mathrm{m}$ foram cortados e colocados sobre lâminas silanizadas. As lâminas contendo os cortes foram armazenadas por 24 horas em estufa a 40 ㅇ․ Estes foram desparafinizados em dois banhos de xilol, sendo o primeiro a $60^{\circ} \mathrm{C}$ por 30 minutos e o segundo à temperatura ambiente por 20 minutos. A seguir os cortes foram re-hidratados em cadeia descendente de etanol (100\%, 95\%, $85 \%$, respectivamente) e posteriormente incubados em solução de $10 \%$ de hidróxido de amônio em álcool 95\% por 10 minutos, para remoção dos pigmentos formólicos depositados no tecido. Os cortes foram então imersos em solução em água tratada com diethyl pirocarbonato (DEPC).

\subsubsection{Pré-hibridização}

Os cortes foram incubados em PBS-DEPC contendo $100 \mathrm{mM}$ de glicina (duas trocas de cinco minutos). Em seguida, foram tratados com PBS-DEPC contendo 2\% de Triton $^{\circledR}$ X-100 por 15 minutos para permeabilização da membrana celular e 
lavados em duas trocas de PBS-DEPC. A seguir, digestão tecidual foi realizada por 10 minutos a $37^{\circ} \mathrm{C}$ com tampão PBS, contendo de $25 \mu \mathrm{g} / \mathrm{ml}$ de Proteinase $\mathrm{K}$ (livre de RNAse), seguida de lavagem em PBS-DEPC (duas trocas de cinco minutos). A seguir, os cortes foram incubados com $\mathrm{H}_{2} \mathrm{O}_{2} 10 \mathrm{~V}$ por 20 minutos a fim de se bloquear a peroxidase endógena e então lavados em PBS-DEPC (duas trocas de cinco minutos). Seguiu-se incubação com leite Molico a $10 \%$ em PBS por 60 minutos. Após nova lavagem com PBS (duas trocas de cinco minutos) os cortes foram acetilados (duas trocas de cinco minutos) por meio de incubação em solução de TEA (trietanolamine) $0.1 \mathrm{M}, \mathrm{pH} 8.0$, contendo $0.25 \%$ de acético anidro e finalmente incubados em placa quente a 95 ㄷ $\mathrm{C}$ por sete minutos em solução tampão de hibridização.

\subsubsection{Hibridização in situ}

O excesso de tampão de hibridização foi removido por meio de cuidadosa secagem com papel de filtro e então os cortes foram incubados com a sonda para integrina $\beta 1$ marcada com biotina, diluída em tampão de hibridização* . A incubação foi realizada a 55ํC "overnight" em câmara úmida. Controles negativos foram incubados com a sonda "scramble" e apenas com tampão de hibribrização, sem sonda. 


\subsubsection{Tampão de hibridização:}

Formamida deionizada, 50\% de sulfato de dextran, 50X solução Denhardt, 20XSSC, $10 \mathrm{mM}$ DTT, $10 \mathrm{mg} / \mathrm{ml} \mathrm{H}_{2} \mathrm{O}$ de yeast t-RNA, $10 \mathrm{mg} / \mathrm{ml} \mathrm{H}_{2} \mathrm{O}$ de DNA de esperma de salmão, $1 \mathrm{mg} / \mathrm{ml} \mathrm{H}_{2} \mathrm{O}$ PolyA-PolyC, $10 \mathrm{mg} / \mathrm{ml}$ pirofosfato inorgânico em TRIS $1 \mathrm{M} \mathrm{pH} 7.4$

\subsubsection{Pós-hibridização}

A sonda foi removida por meio de quatro lavagens de 15 minutos com $2 \mathrm{X}$ SSC contendo $2 \%$ de Tween 20 e $0.1 \%$ de soro fetal bovino a $45^{\circ} \mathrm{C}$. Os cortes foram então incubados por 30 minutos a $37^{\circ} \mathrm{C}$ em tampão SSC contendo $20 \mu \mathrm{g} / \mathrm{ml}$ de Rnase $\mathrm{A}(500 \mathrm{mM}$ de $\mathrm{NaCl}, 10 \mathrm{mM}$ de TRIS, $1 \mathrm{mM}$ de EDTA, pH 8.0), para digestão de possíveis remanescentes de sonda não hibridizada e lavados ( $2 \times 30$ minutos a $37^{\circ} \mathrm{C}$ ) em 0.1XSSC.

A deteç̧ão da sonda foi realizada por meio de uso do Kit GEN POINT (DAKO), cujos passos são brevemente descrito a seguir:

A. Incubação com anticorpo primário streptavidina HRP (1:300) por 20 minutos;

B. Incubação com biotinil-tiramida por 20 minutos;

C. Incubação com anticorpo secundário HRP por 20 minutos;

D. Incubação com 3'3 diaminobenzidina por três minutos; 
Cada um desses passos foi precedido por quatro lavagens de cinco minutos com PBS em temperatura ambiente.

Os cortes foram então contracorados com hematoxilina de Carazzi por cinco minutos, desidratados em cadeia ascendente de álcoois e montados em resina Permount, e finalmente visualizados em microscopio óptico.

Controles positivos internos como músculo e epitélio de revestimento foram considerados. Dois controles negativos foram utilizados. Um controle da reação, incubando os cortes só com tampão de hibridização, substituindo a sonda, e outro utilizando a sonda "scramble".

\subsection{Análise dos resultados obtidos}

Foram consideradas positivas as células marcadas e identificadas pela coloração castanho-dourada. Todos os resultados foram analisados de forma qualitativa utilizando-se microscópio ótico convencional-e considerados de acordo com a fase da morfogênese glandular.

O registro dos resultados foi realizado por meio de fotomicrografia digital com aparelho fotográfico acoplado ao microscópio óptico, marca Nikon, EclipseE200. 


\section{RESULTADOS}




\section{RESULTADOS}

Os fetos obtidos e utilizados no presente estudo variavam entre 4 e 25 semanas de vida intra-uterina (VIU) sendo, 4 semanas ( 1 feto), 12 semanas ( 2 fetos), 14 semanas ( 3 fetos), 16 semanas ( 3 fetos), 17 semanas ( 1 feto), 18 semanas ( 2 fetos), 19 semanas ( 3 fetos), 20 semanas ( 5 fetos), 21 semanas ( 5 fetos), 22 semanas ( 2 fetos), 23 semanas ( 1 feto), 25 semanas ( 2 fetos).

Exemplos das estruturas dissecadas estão ilustrados na Figura 2. 

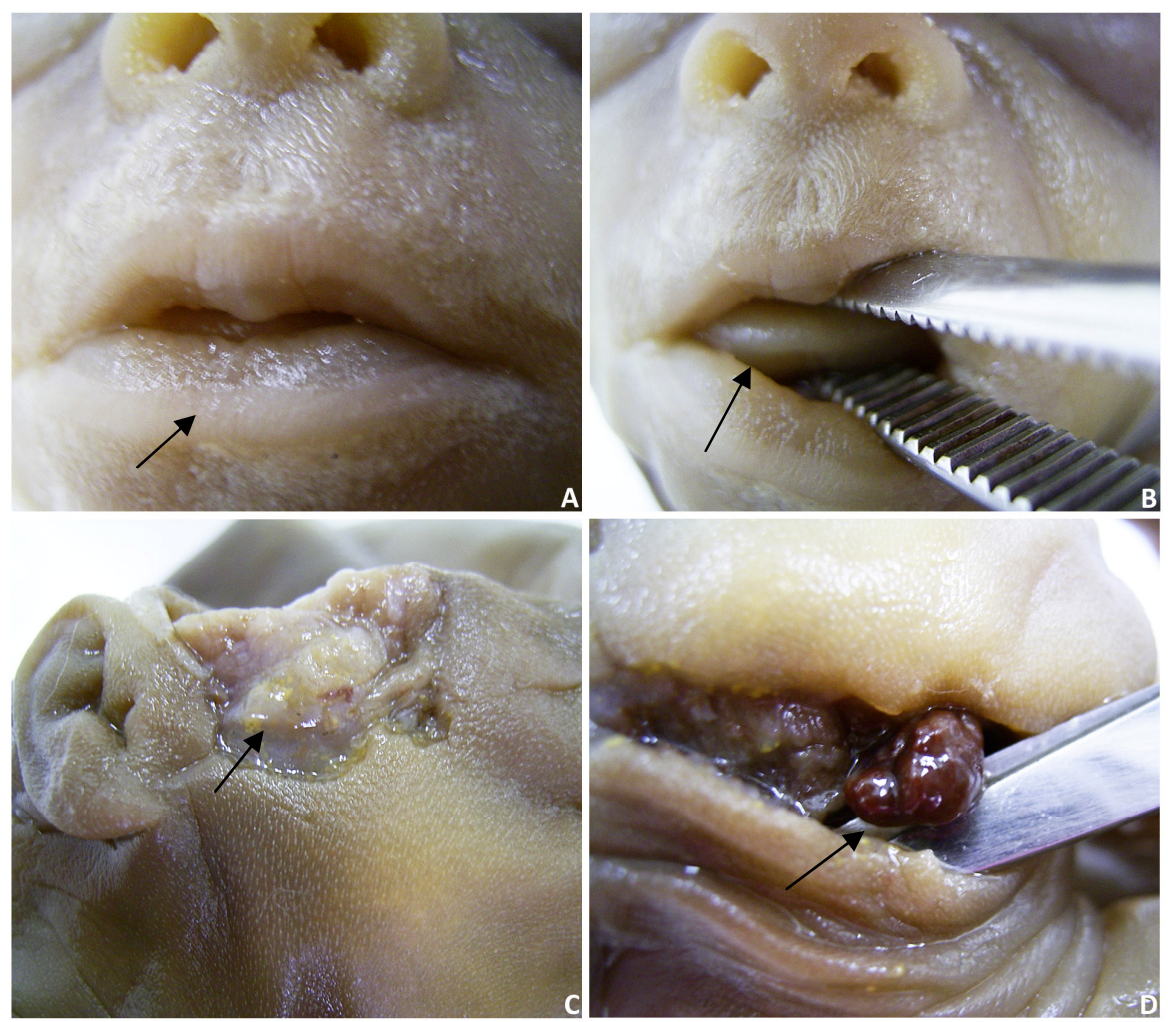

FIGURA 2 
FIGURA 2: EXEMPLOS DE ESTRUTURAS ANATÔMICAS QUE APRESENTAM ESTRUTURA DE GLÂNDULAS SALIVARES EM DESENVOLVIMENTO.
A: Lábio superior e inferior de feto de 23 semanas de vida intra-uterina.
B: Língua (feto de 23 semanas de vida intra-uterina).
C: Glândula parótida em posição anatômica (cabeça de seta). Notar a morfologia plana da glândula que ainda se encontra em fase precoce do seu desenvolvimento.
D: Glândula submandibular (estrutura circular e acastanhada), localizada na face interna da mandíbula nessa fase (feto de 23 semanas de vida intra-uterina). 


\subsection{RESULTADOS MORFOLÓGICOS}

\section{FETO COM 4 SEMANAS DE VIDA INTRA-UTERINA}

Nesta fase do desenvolvimento fetal identificou-se apenas a presença de cavidade oral primitiva revestida por epitélio simples, por vezes de duas camadas. Ainda não se observam vestígios que remontem à presença de rudimentos glandulares.

\section{FETO COM 12 SEMANAS DE VIDA INTRA-UTERINA}

Foram observados brotos de glândulas salivares menores no lábio superior, no palato posterior, na mandíbula e no soalho bucal. Esses brotos epiteliais sólidos eram compostos por células cubóides irregulares, de aspecto basalóide e indiferenciado.

Na língua e no lábio inferior, após cortes seriados realizados em todo o espécime, não foi observada a formação de glândulas salivares menores.

Nesse espécime não foi possível a dissecção íntegra das glândulas parótida e submandibular. 


\section{FETOS COM 14 SEMANAS DE VIDA INTRA-UTERINA}

Nesse período as glândulas salivares menores foram observadas no lábio inferior, na mucosa jugal, na porção anterior da língua e no palato posterior, exibindo alguns cordões epiteliais ramificados, correspondendo ao terceiro estágio do desenvolvimento glandular.

No soalho bucal e na mandíbula as glândulas salivares menores foram observadas no estágio de canalização, tendo em vista que foi notado o aparecimento de ductos, túbulos e sacos terminais.

Nos espécimes do lábio superior, mucosa jugal esquerda, mucosa jugal direita, porção posterior da língua e palato anterior não foram observadas glândulas salivares em desenvolvimento.

As glândulas parótida e submandibular apresentavam estruturas epiteliais nos estágios de broto, ramificação epitelial e algumas estruturas em fase de canalização. As células epiteliais exibiam núcleo amplo, citoplasma eosinofílico e, por vezes as estruturas epiteliais mostravam-se contornadas por células fusiformes ou estrelárias. A presença de lóbulos glandulares já se fazia evidente e estes eram separados entre si por um contorno de tecido conjuntivo frouxo bem vascularizado. 


\section{FETOS COM 16-18 SEMANAS DE VIDA INTRA-UTERINA}

No lábio superior, as glândulas salivares mostravam numerosas ramificações correspondendo ao estágio de botão inicial. No lábio inferior e mucosa jugal direita foram observadas glândulas salivares menores no estágio pseudo glandular.

Na mucosa jugal esquerda e na porção anterior da língua, as glândulas salivares menores encontravam-se no início do estágio canalicular, enquanto que na porção posterior da língua, do palato posterior, da mandíbula e do soalho foi observado o estágio de botão terminal.

No estágio canalicular inicial, as células epiteliais dos sacos terminais começavam a exibir citoplasma amplo, claro, e com grânulos no seu interior. Enquanto que as demais células do túbulo terminais possuíam ainda um aspecto indiferenciado, cubóide, irregular, com citoplasma escasso e núcleo volumoso. Portanto, nesse estágio, ficou caracterizado o início da diferenciação morfológica dos ácinos.

No estágio de botão terminal, as porções terminais das glândulas salivares menores exibiam células acinares morfologicamente diferenciadas, apresentando aspecto piramidal, citoplasma amplo, claro, rico em grânulos de secreção e núcleo achatado, situado no pólo basal da célula. Nesta fase, os túbulos terminais eram compostos por duas camadas de células, e ao redor das células acinares notaram-se células de aspecto fusiforme, com núcleo achatado e central, interpretadas como prováveis células mioepiteliais. 
Nas glândulas parótida e submandibular, as estruturas glandulares apresentavam nuances entre os estágios pseudo glandular e canalicular inicial, com a evidência de estruturas que exibiam sacos terminais rudimentares, com células epiteliais de citoplasma amplo e claro.

\section{FETOS COM 19-21 SEMANAS DE VIDA INTRA-UTERINA}

Nos lábios, na mucosa jugal e na língua foram observadas glândulas salivares menores no estágio canalicular.

Em outros locais - palato, mandíbula e soalho - as glândulas salivares exibiam aspecto morfológico de botão inicial.

Nas glândulas parótida e submandibular, observavam-se estruturas nos estágios pseudo glandular. Já se podia observar lóbulos glandulares bem formados com evidente separação por septo fibrovascular e estruturas epiteliais contornadas por células fusiformes e estrelárias. Algumas estruturas ductais já canalizadas encontravam-se mais maduras exibindo epitélio glandular pluriestratificado. Entretanto, ao longo do exame dessas glândulas ainda se notava presença de raras estruturas menos diferenciadas, no estágio de ramificação epitelial e ductos recém-canalizados, com apenas uma camada de células de núcleo amplo e citoplasma eosinofílico. 
FETOS COM 22-25 SEMANAS DE VIDA INTRA-UTERINA:

As glândulas salivares identificadas nas estruturas dissecadas exibiam estágio de botão terminal com sacos terminais bem diferenciados exibindo células de citoplasma amplo e claro, por vezes com presença de grânulos. Ainda podiam-se observar estruturas menos diferenciadas nos estágios de botão terminal de diferenciação acinar. Muitas estruturas ductais nessa fase já exibiam pluriestratificação e os lóbulos de glândulas salivares encontravam-se bem delimitados por septos fibrovasculares.

Nas glândulas parótida e submandibular, a diferenciação também já se encontra mais avançada com maior número de estruturas na fase de canalicular e botão terminal. Os lóbulos glandulares encontram-se bem formados e as estruturas glandulares bem organizadas, muitas delas contornadas por células fusiformes ou estrelárias. Os ductos excretores mostram pluriestratificação e os sacos terminais, células de citoplasma amplo, às vezes exibindo grânulos citoplasmáticos.

Como se pode notar, o desenvolvimento das glândulas salivares ocorre em etapas diferentes em um mesmo feto, dependendo do local anatômico, isto é, em um mesmo espécime pudemos encontrar estruturas glandulares em estágios diferentes de sua diferenciação. Dessa forma, para maior facilidade de estudo, dividimos as estruturas glandulares segundo sua etapa de desenvolvimento, e não segundo a idade fetal. Assim, analisaremos nossa amostra segundo o seguinte critério.

Essas fases estão ilustradas na Figura 3. 


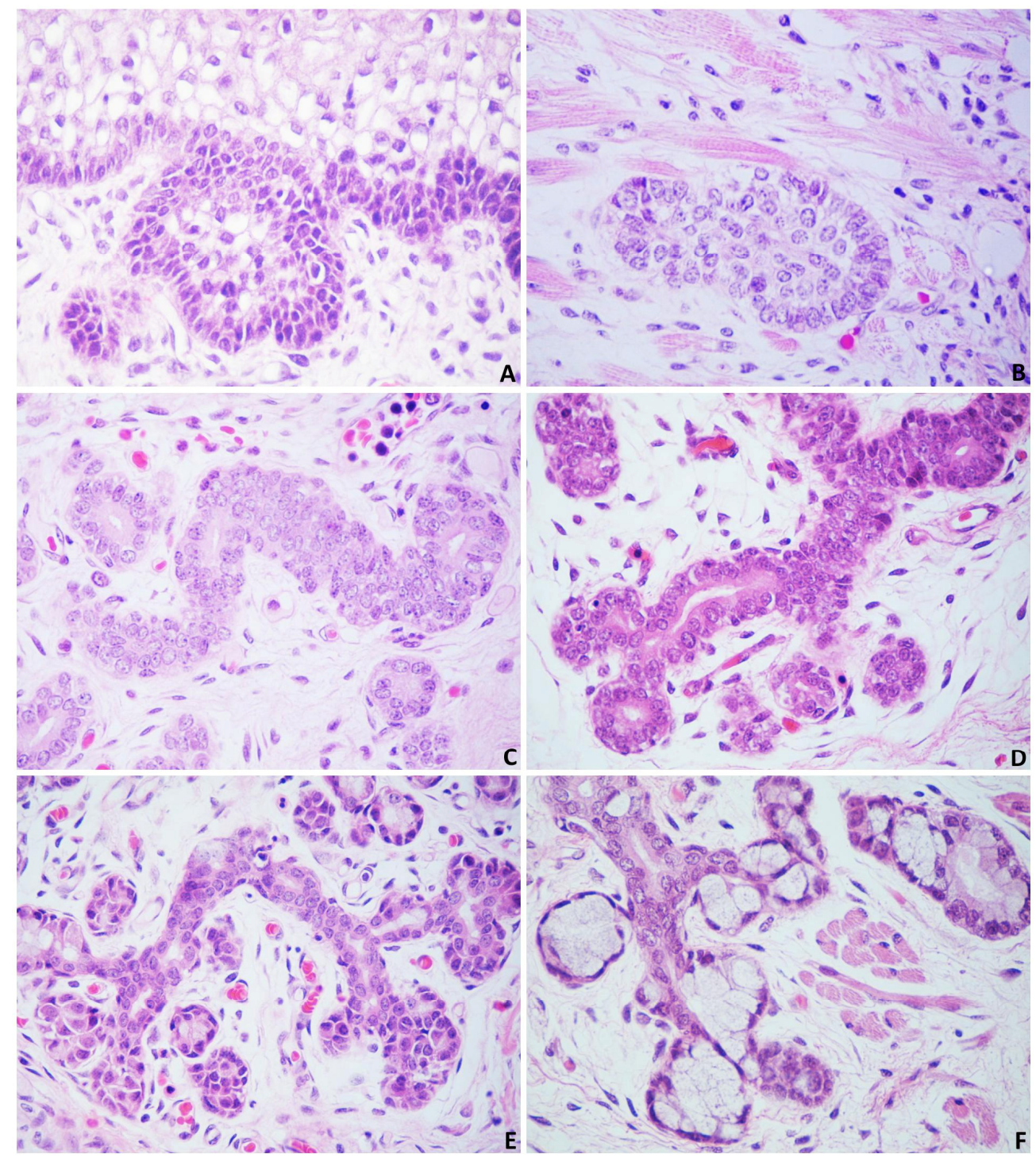

FIGURA 3 
Figura 3: Estágios de diferenciação das glândulas salivares

A: Fase de pré-botão composto por células de aspecto basalóide e indiferenciado (hematoxilina/eosina, aumento original $\mathrm{X} 400$ )

B: Cordões epiteliais ramificados e presença de algumas estruturas exibindo início de lúmen central (hematoxilina/eosina, aumento original X400)

C: Cordões epiteliais sólidos com início de canalização (hematoxilina/eosina, aumento original $\mathrm{X} 400$ )

D: Ducto excretor canalizado e exibindo estratificação epitelial (hematoxilina/eosina, aumento original $\mathrm{X} 400$ )

E: Início da canalização com presença de sacos terminais rudimentares (hematoxilina/eosina, aumento original X400)

F: Glândula salivar mucosa: botão terminal com estruturas acinares morfologicamente diferenciadas, com células de citoplasma amplo e claro e aspecto piramidal (hematoxilina/eosina, aumento original X400) 


\subsection{Resultados da hibridização in situ}

\section{FASE DE PRÉ-BOTÃO}

Poucas estruturas glandulares foram observadas na fase de pré-botão, uma vez que a maioria dos fetos obtida encontrava-se em fases mais avançadas do desenvolvimento fetal. Entretanto, as estruturas identificadas como pré-botão apresentavam raras células expressando integrina $\beta 1$. Quando identificada a expressão, esta se mostrava como fina linha ao redor do núcleo (posição paranuclear) (Figura 4A).

\section{FASE DE BOTÃO EPTELIAL:}

Nesse estágio, a expressão da integrina $\beta 1$ foi observada em raras células epiteliais, de citoplasma amplo e basofílico. A expressão da integrina $\beta 1$ foi notada em padrão do tipo linha paranuclear, ou em forma de pontos, com marcação bipolar ou contornando o núcleo celular (Figura 4B).

\section{FASE PSEUDO-GLANDULAR:}

A maior parte dos espécimes analisados exibia glândulas salivares nesse estágio de diferenciação. No ducto já canalizado, a expressão genética da integrina 
$\beta 1$ foi variável. Nos ductos canalizados das glândulas maiores (parótida e submandibular), o padrão de expressão da integrina $\beta 1$ foi similar ao visto na etapa anterior - apenas algumas células expressavam a sequência genética e esta aparecia em posição paranuclear. Já nas glândulas menores, a expressão da integrina $\beta 1$ foi mais abundante, estando presente em maior número de células e apresentando padrão de expressão em forma de pontos bipolares paranucleares, ou até mesmo contornando o núcleo celular (Figuras 4C-4D).

\section{CANALICULAR:}

Expressão da integrina $\beta 1$ apenas em células de núcleo amplo e nucléolo evidente, nas extremidades dos sacos terminais. Essa expressão é discreta, restringindo-se a poucas células. As estruturas ductais canalizadas e bem diferenciadas apresentavam expressão da integrina $\beta 1$ de forma mais abundante, contornando os núcleos das células luminais, e, por vezes, exibindo padrão polarizado de expressão (Figura 4E-4F-5A-5B-5Ce5D).

\section{BOTÃO TERMINAL:}

Raras células das estruturas acinares bem diferenciadas exibiam expressão de integrina $\beta 1$ (Figura 5E-5F). Nas estruturas ductais a expressão da integrina $\beta 1$ foi muito mais abundante, estando presente de forma mais ampla nas células epiteliais dos ductos bem diferenciados e algumas vezes pluri-estratificados. 


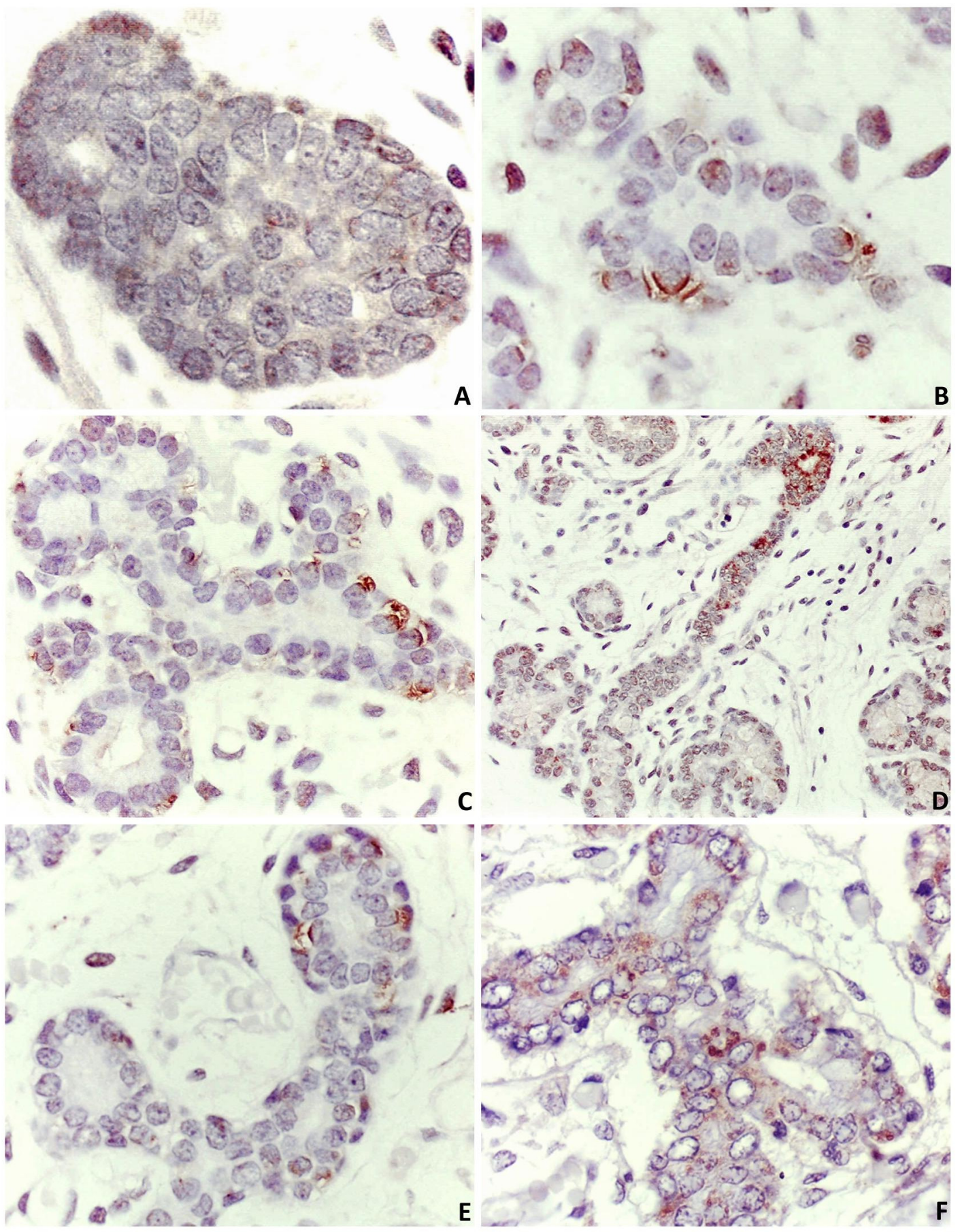

FIGURA 4 
Figura 4: Expressão da integrina $\beta 1$ no desenvolvimento das glândulas salivares humanas (hibridização in situ)

A: Fase de pré-botão: células de aspecto basalóide indiferenciadas exibindo rara expressão de integrina $\beta 1$.

B: Início da fase pseudoglandular: broto epitelial em início de ramificação mostrando expressão de integrina $\beta 1$ em poucas células em padrão linear paranuclear.

C: Fase pseudoglandular: maior número de células expressando integrina $\beta 1$ em posição paranuclear.

D: Estrutura glandular composta de ramos epiteliais e estrutura ductal rudimentar. Expressão de integrina $\beta 1$ é mais intensa na porção do ducto ramificado.

E: Estrutura epitelial em fase canalicular mostrando expressão de integrina $\beta 1 \mathrm{em}$ células epiteliais de núcleo amplo e claro em posição paranuclear (padrão linear).

F: Fase canalicular: raras células exibem expressão de integrina $\beta 1$ em forma de pontos e "clusters" circundando toda a periferia nuclear. 


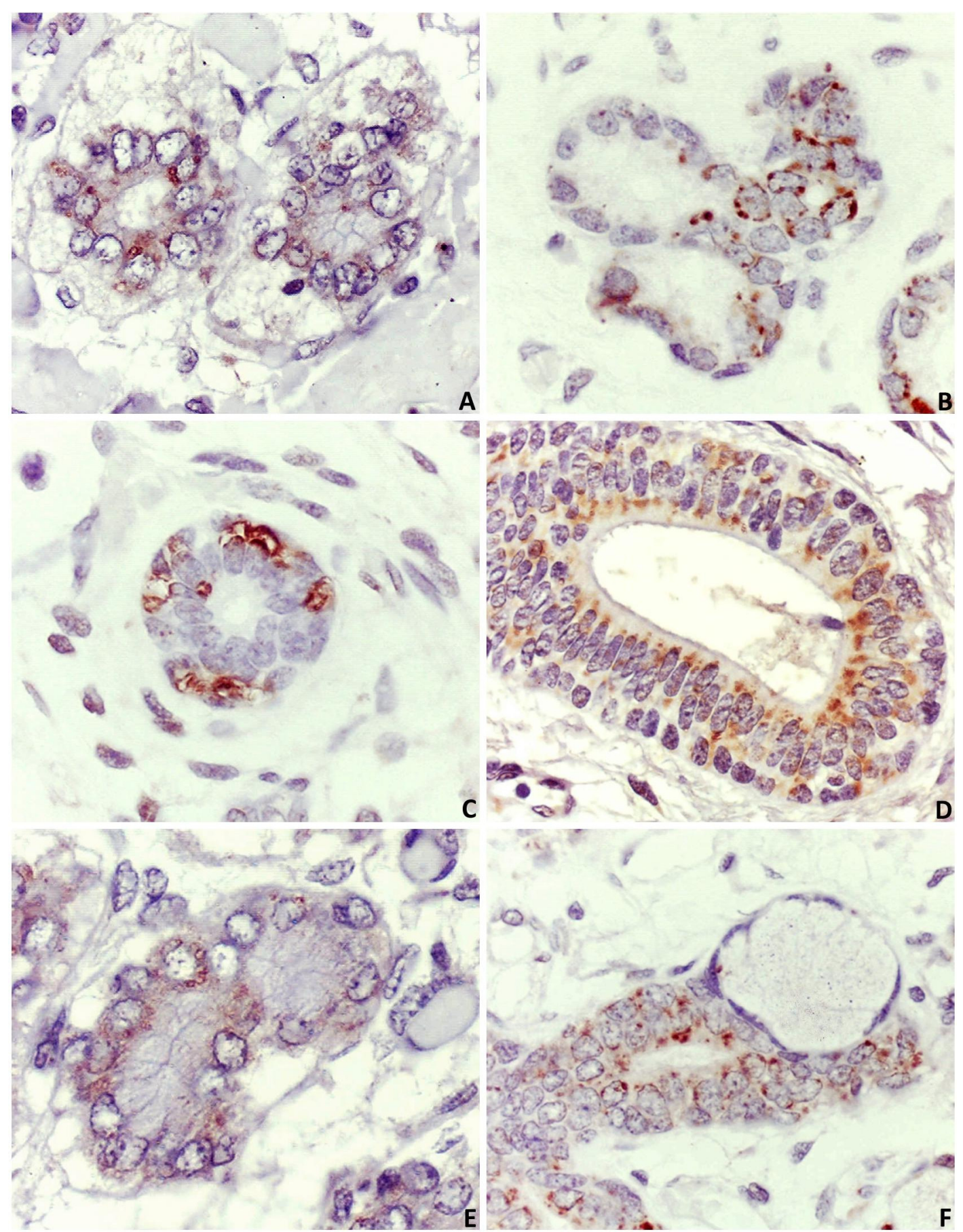

FIGURA 5 
Figura 5: Expressão da integrina $\beta 1$ no desenvolvimento das glândulas salivares humanas (hibridização in situ)

A: Fase canalicular: células exibindo expressão de integrina $\beta 1$ em forma de pontos esféricos ao redor do núcleo.

B: Fase canalicular: expressão de integrina $\beta 1$ circundando o núcleo celular das estruturas que exibem lúmen desenvolvido.

C: Ducto canalizado: expressão de integrina $\beta 1 \mathrm{em}$ halo paranuclear

D: Ducto excretor canalizado e morfologicamente diferenciado exibindo expressão de integrina $\beta 1$ em pontos por vezes bipolares em posição paranuclear E: Fase de botão final: células exibindo expressão de integrina $\beta 1$ em forma de pontos esféricos ao circunjacentes ao núcleo celular

F: Fase de botão final: estrutura acinar não mostra expressão de integrina $\beta 1$. Esta molécula é evidenciada apenas a partir do segmento ductal em forma de pontos paranuclares. 
Tabela 1 - Análise semi-quantitativa da expressão da integrina $\beta 1$ durante as diferentes fases morfogênese das glândulas salivares humanas e na glândula salivar plenamente desenvolvida (fase adulta) verificada pela técnica de hibridização in situ.

\begin{tabular}{|c|c|c|c|}
\hline & & & $\begin{array}{c}\text { Integrina } \beta 1 \\
\text { Hibridização in situ }\end{array}$ \\
\hline \multirow{7}{*}{$\begin{array}{l}\text { MORFOGÊNESE } \\
\text { DAS GLÂNDULAS } \\
\text { SALIVARES } \\
\text { HUMANAS }\end{array}$} & $\begin{array}{c}\text { ESTÁGIO DE PRÉ BOTÃO/ } \\
\text { BOTÃO INICIAL }\end{array}$ & células epiteliais & + \\
\hline & $\begin{array}{c}\text { ESTÁGIO } \\
\text { PSEUDOGLANDULAR }\end{array}$ & cordões epiteliais & + \\
\hline & & células ductais & ++ \\
\hline & & células mioepiteliais & 0 \\
\hline & \multirow{3}{*}{$\begin{array}{c}\text { ESTÁGIO DE BOTÃO } \\
\text { TERMINAL }\end{array}$} & células ductais & +++ \\
\hline & & células acinares & + \\
\hline & & células mioepiteliais & 0 \\
\hline \multirow{3}{*}{$\begin{array}{c}\text { GLÂNDULA } \\
\text { SALIVAR HUMANA } \\
\text { PLENAMENTE } \\
\text { DESENVOLVIDA }\end{array}$} & & células ductais & +++ \\
\hline & & células mioepiteliais & 0 \\
\hline & & células acinares & + \\
\hline
\end{tabular}

0: negativo

+: positividade em células isoladas

++: positividade poucas células

+++: positividade em muitas células 


\section{DISCUSSÃO}

Pouco se sabe sobre os mecanismos que regulam o desenvolvimento das glândulas salivares humanas. Como outras glândulas e tecidos, é muito provável que o desenvolvimento seja coordenado por meio de vários eventos integrados que afetam a proliferação, a morfogênese e as interações célula/matriz extracelular. Estes eventos são altamente regulados tanto temporalmente como espacialmente (Cutler, 1989). Nas glândulas salivares estes eventos provavelmente passam a influenciar sua morfogênese por volta da sexta semana do desenvolvimento fetal, quando células específicas do eptélio oral se submetem a um crescimento baseado em interações eptélio-mesênquima, levando a eventos relacionados com sua formação e citodiferenciação (Cutler, 1990; Kashimata e Gresik, 1996).

Com relação aos aspectos morfológicos das glândulas salivares, observamos, em nosso material, a partir da 9a semana de vida intrauterina, a presença de brotos epteliais em forma de espessamentos. Estes espessamentos eram compostos de células epiteliais de aspecto ainda indiferenciado e/ou basalóide e originados a partir do epitélio do revestimento em diferentes locais anatômicos. Estes achados corroboram os de outros autores (Zimmerman e Zeidenstein, 1951; Muller et al, 1991; Dale, 1994) que observaram o início da formação das glândulas salivares por volta da 9ạ-10a semana de VIU.

A partir desta fase inicial do desenvolvimento das glândulas salivares, as células epiteliais formaram cordões sólidos que se ramificaram e posteriormente se 
canalizaram e, em fases mais tardias, formaram as unidades acinares secretórias das glânduals salivares.

Notamos em nosso estudo, que a cronologia do desenvolvimento variou de acordo com o local anatômico da glândula, e também, que em uma mesma glândula, existiam estruturas em fases diferentes da morfogênese. Nesta observação constatamos que as glândulas do soalho bucal e as submandibulares eram as mais desenvolvidas morfologicamente nos tempos embriológicos estudados.

Esse fato pode estar relacionado com a etapa do desenvolvimento e a relação das células que formarão o parênquima glandular com o micro-ambiente em que as glândulas salivares se inserem, e pode denotar prováveis influências do micro-ambiente em mecanismos complexos de expressão genética e cascatas de sinalização que culminem com a diferenciação das estruturas epiteliais glandulares.

As integrinas parecem ser as moléculas chave nos processos de interação das células epiteliais glandulares com o micro-ambiente (epitélio-mesênquima) e as perturbações da sua expressão podem levar à má formação e função glandular deficiente. Menko e colaboradores (2001) demonstraram que a ausência do dímero integrina alfa3 $\beta 1$ afeta vários componentes do complexo de adesão e suas vias de sinalização associadas às glândulas salivares, como por exemplo, Cdc42 e RhoA e duas Rho GTPases, que regulam a organização do citoesqueleto de actina.

O papel da integrina $\beta 1$ tem sido investigado em outros tecidos e a sua importância nos processos de desenvolvimento dos mesmos está sendo estabelecido. Nas glândulas mamárias que apresentam uma morfologia similar às 
das glândulas salivares, a alteração da integrina $\beta 1$ resulta um desenvolvimento e diferenciação precários do epitélio secretor (Faraldo et al., 1998).

Seguindo a mesma linha de estudo, Naylor e colaboradores (2005), demonstraram que o distúrbio no desenvolvimento lobular das glândulas mamárias em camundongos se deve à falta da integrina $\beta 1$, que se manifesta como alteração na proliferação epitelial, desencadeada pela ausência desta molécula.

Nossos estudos concluíram que durante os estágios iniciais da morfogênese das glândulas salivares - pré-botão e botão inicial - a integrina $\beta 1$ estava presente em raras células e aumentou à medida que a diferenciação progredia. Estes resultados sugerem que a integrina $\beta 1$ é importante na fase inicial do desenvolvimento, quando ocorrem as interações entre células do botão epitelial e o meio extracelular recentemente formado.

No estágio pseudoglandular, a integrina $\beta 1$ se apresentou em forma de anel em algumas células ductais. Esses resultados foram semelhantes aos resultados de outros autores, cujos estudos sugeriram que a presença da integrina $\beta 1$ pode ser uma proteína indicadora do nicho de células-tronco mamárias e cutâneas (Watt et al., 2000). Nesta situação, a integrina $\beta 1$ parece impedir que a falta de adesão eficiente direcione tais células para processos de diferenciação terminal (Watt e Hoogan, 2000). Além disto, proteínas da matriz-extracelular podem modular a expressão e a ativação das integrinas $\beta 1$ nestas células, e a variação local na composição da membrana basal durante o desenvolvimento glandular pode ter uma função no estabelecimento e manutenção da sua distribuição (Watt et al., 2000). 
No estágio canalicular avançado do desenvolvimento da glândula salivar, a integrina $\beta 1$ estava presente em um grande número de células, com sinais detectados na membrana perinuclear ou citoplasma. A localização diferencial do mRNA pode refletir um novo tipo de controle pós-transcricional envolvido em muitos processos celulares, incluindo a regulação da assimetria celular necessária para a criação e manutenção da polarização celular, sendo imprescindível para a diferenciação e desenvolvimento da célula. Portanto, a localização específica do mRNA no citoplasma pode fornecer um mecanismo importante, através do qual proteínas especializadas podem ser expressas sutilmente dentro da célula (Jansen e Kiebler, 2005; Czaplinsk e Singer, 2006).

Nas glândulas salivares em desenvolvimento, a presença da integrina $\beta 1$ nestes locais pode ser importante para transcrição local da proteína que posteriormente determinará a polaridade celular, preparando as estruturas glandulares para suas funções secretoras. Além disso, algumas células ainda mantiveram o padrão de expressão da integrina $\beta 1$ em forma de anel. Outras células do sistema ductal ramificado expressaram a integrina $\beta 1$ na membrana basolateral.

Este padrão morfológico variado sugere que as integrinas possam desempenhar diferentes papéis no processo de desenvolvimento das glândulas salivares, tanto na diferenciação e manutenção de fenótipo, mediando uma íntima relação entre parênquima celular e matriz-extracelular, assim como estar associado às funções glandulares. Pensa-se que este padrão de distribuição esteja envolvido na ligação estável de células epiteliais em íntimo contato com matriz extracelular e 
na manutenção das interações intercelulares (Coraux et al., 2000). Mais uma vez, acredita-se que a expressão da integrina $\beta 1$ possa ser um indicador de membrana celular de células-tronco/pluripotentes nos passos evolucionários da morfogênese das glândulas salivares. Além disso, esta molécula tem provável função de adesão para proliferação e diferenciação celular (Lourenço e Kapas; 2005).

Nas fases avançadas do desenvolvimento das glândulas salivares (botão terminal) indicado pela ramificação e citodiferenciação das células acinares, a integrina $\beta 1$ imita os padrões vistos nas estruturas das glândulas salivares adultas normais. Portanto, a integrina $\beta 1$ mostrou expressão citoplasmática no polo apical das células luminais, assim como nas porções basolaterais das células ductais. Este fenômeno pode ser responsável pelas funções secretoras das glândulas salivares e é semelhante ao que tem sido observado em outros órgãos secretores, como estômago e mama (Chénard et al., 2000; Li et al., 2005). O aumento na expressão da integrina $\beta 1$ durante o desenvolvimento e diferenciação das glândulas salivares confirma a importância desta molécula na manutenção das funções específicas de cada tecido.

Nosso grupo vem estudando esses aspectos moleculares de interação epitélio/mesênquima, em especial, das integrinas, durante o desenvolvimento das glândulas salivares. O presente estudo, nesse contexto contribuiu, de forma efetiva, para a detecção dessas moléculas em fases mais precoces da morfogênese glandular, devido a sensibilidade da técnica empregada (hibridização in situ). Essa maior sensibilidade na deteç̧ão da integrina beta-1 pode ser comparada aos 
resultados previamente publicados utilizando a técnica imunoistoquímica (Lourenço

e Kapas, 2005) na tabela abaixo:

Tabela 2: Expressão da integrina beta-1 durante as diferentes fases morfogênese das glândulas salivares humanas: análise comparativa da sensibilidade de detecção da proteínas pelas técnicas imunistoquímica e hibridização in situ

\begin{tabular}{|c|c|c|c|c|}
\hline & & & $\begin{array}{c}\text { Integrina } \beta 1 \\
\text { imunoistoquímica } \\
\text { (Lourenço e Kapas, } \\
\text { 2005) }\end{array}$ & $\begin{array}{c}\text { Integrina } \beta 1 \\
\text { Hibirdização in } \\
\text { situ } \\
\text { (trabalho atual) }\end{array}$ \\
\hline \multirow{7}{*}{$\begin{array}{l}\text { MORFOGÊNESE } \\
\text { DAS GLÂNDULAS } \\
\text { SALIVARES } \\
\text { HUMANAS }\end{array}$} & $\begin{array}{c}\text { ESTÁGIO DE PRÉ } \\
\text { BOTÃO/ BOTÃO } \\
\text { INICIAL }\end{array}$ & $\begin{array}{l}\text { células } \\
\text { epiteliais }\end{array}$ & 0 & + \\
\hline & $\begin{array}{c}\text { ESTÁGIO } \\
\text { PSEUDOGLANDULAR }\end{array}$ & $\begin{array}{l}\text { cordões } \\
\text { epiteliais }\end{array}$ & 0 & + \\
\hline & \multirow{2}{*}{$\begin{array}{c}\text { ESTÁGIO } \\
\text { CANALICULAR }\end{array}$} & células ductais & + & ++ \\
\hline & & $\begin{array}{c}\text { células } \\
\text { mioepiteliais }\end{array}$ & 0 & 0 \\
\hline & \multirow{3}{*}{$\begin{array}{c}\text { ESTÁGIO DE BOTÃO } \\
\text { TERMINAL }\end{array}$} & células ductais & ++ & +++ \\
\hline & & células acinares & + & + \\
\hline & & $\begin{array}{c}\text { células } \\
\text { mioepiteliais }\end{array}$ & 0 & 0 \\
\hline \multirow{3}{*}{$\begin{array}{c}\text { GLÂNDULA } \\
\text { SALIVAR HUMANA } \\
\text { PLENAMENTE } \\
\text { DESENVOLVIDA }\end{array}$} & & células ductais & +++ & +++ \\
\hline & & $\begin{array}{c}\text { células } \\
\text { mioepiteliais }\end{array}$ & 0 & 0 \\
\hline & & células acinares & + & + \\
\hline
\end{tabular}

0 : negativo

+: positividade em células isoladas

++: positividade poucas células

+++: positividade em muitas células 
Essa detecção da subunidade de integrina beta-1, por meio da hibridização in situ, em fases mais precoces do desenvolvimento glandular, reforça a hipótese de que a molécula é fundamental no processo de morfogênese das glândulas salivares e abre novas possibilidades de investigação e busca de elementos que possam eventualmente demonstrar, de forma inequívoca, o seu envolvimento com as células-tronco/multipotentes do compartimento regenerador das glândulas salivares - a porção ductal (ducto intercalado).

Em síntese, nosso estudo mostrou que as integrinas são moléculas relevantes no desenvolvimentos das glândulas salivares, e funcionou como um ponto de partida para investigações mais profundas do tema. As hipóteses aventadas em nossa discussão baseada no conjunto de resultados apresentados, só poderão ser esclarecidas com estudos funcionais envolvendo técnicas de cultivo celular, animais experimentais e técnicas de ponta na área da biologia molecular de sinalização intracelular. 
7 CONCLUSÕES 


\section{CONCLUSÕES}

Nosso estudo mostrou que:

A. A integrina $\beta 1$ estava presente desde as fases iniciais do desevolvimento das glândulas salivares.

B. A expressão da integrina $\beta 1$ foi detectada em células do sistema ductal das glândulas salivares.

C. O aumento da expressão da integrina $\beta 1$ durante o desenvolvimento e diferenciação das glândulas salivares confirmou a importância desta molécula na manutenção das funções específicas deste órgão.

D. A técnica de hibridização in situ é mais sensível que a técnica in situ de imunoistoquímica para a detecção da integrina $\beta 1$ nas diferentes fases da morfogênese das glândulas salivares humanas. 


\section{REFERÊNCIAS}

Adi MM; Chisholm DM; Waterhouse JP. Sterological and immunohistochemical study of development of human fetal labial salivary glands and their S-100 protein reactivity. J Oral Pathol Med. 1984;23:36-40.

Azuma M, Sato M. Morphogenesis of normal human salivary gland cells in vitro. Histol Histopath. 1994;9:781-90.

Bagutti C, Hutter C, Chiquet-Ehrismann R, Fässler R, Watt FM. Dermal fibroblastderived growth factors restore the ability of $\beta 1$ integrin-deficient embryonal stem cells to differentiate into keratinocytes. Dev Biol. 2001;231:321-33.

Batsakis JG. Salivary gland neoplasia: an outcome of modified morphogenesis and cytodifferentiation. Oral Surg Oral Med Oral Pathol. 1980;49:229-32.

Batsakis JG, Regezi JA, Luna MA, El Naggar A. Histogenesis of salivary gland neoplasms: a postulate with prognostic implications. J Laryngol Otol. 1989;103: 93944.

Beauvais-Jouneau A, Thierry JP. Multiple roles for integrins during development. . Biol Cell. 1997;89:5-11. 
Berkowitz BKB, Holland GR, Moxham BJ. A colour atlas and textbook of oral anatomy, histology and embryology. 2nd ed. London: Wolfe Publishing; 1992. $328 p$.

Bernfield MR, Banderjee SD, Cohn RH. Dependence of salivary epithelial morphology and branching morphogenesis upon acid mucopolysaccharide-protein (proteoglycan) at epithelial . J Cell Biol. 1972;52:674-89.

Bhaskar SN. Glândulas salivares. In: Histologia e embriologia oral. 8ª ed. São Paulo: Artes Médicas; 1978.

Borghese E. Development in vitro of the submandibular and sublingual glands of Mus musculus. J Anat. 1950;84:287-302.

Boudreau NJ, Jones PL. Extracellular matrix and integrin signalling: the shape of things to come. Biochem J. 1999;339:481-8.

Brakebush C, Grose R, Quondamatteo F, Ramirez A, Jorcano JL, Pirro A, Svensson M, Herken R, Sasaki T, Timpl R, Werner S, Fässler R. Skin and hair follicle integrity is crucially dependent on $\beta 1$ integrin expression on keratinocytes. EMBO J. 2000;19: 3990-4003. 
Chénard M, Basque JR, Chailler P, Tremblay E, Beaulieu JF, Ménard D. Expression of integrin subunits correlates with differentiation of epithelial cell lineages in developing human gastric mucosa. Anat Embryol (Berl). 2000;202:223-33.

Clark EA, Brugge JS. Integrins and signal transduction pathways: the road taken. Science. $1995 ;$ 268:233-9.

Coraux C, Zahm JM, Puchelle E, Gaillard D. $\beta 1$ integrins are involved in migration of human fetal tracheal epithelial cells and tubular morphogenesis. Am J Physiol Lung Cell Mol Physiol. 2000;279:L224-34.

Cutler LS. Functional differentiation of salivary glands. In: Schultz SG, editor. Handbook of physiology. Section 6: the gastrointestinal system. Volume 3: salivary, gastric, pancreatic and hepatobiliary secretion. Bethesda: American Physiological Society; 1989. p.93-105.

Cutler LS. The role of extracellular matrix in the morphogenesis and differentiation of salivary glands. Adv Dent Res. 1990;4:27-33.

Czaplinski K, Singer RH. Pathways for mRNA localization in the cytoplasm. Trends Biochem Sci. 2006;31:687-93. 
Dale AC. Salivary gland: In: Ten Cate AR. Oral histology. 4th ed. St. Louis: Mosby, 1994.

Danen EHJ, Sonnenberg A. Integrins in regulation of tissue development and function. J Pathol. 2003;200:471-80.

Dardick I, Burford-Mason AP. Current status of histogenetic and morphogenetic concepts of salivary gland tumorigenesis. Crit Rev Oral Biol Med. 1993;4:639-77.

Dardick I, Byard RW, Carnegie JA. I. A review of the proliferative capacity of major salivary glands and the relationship to current concepts of neoplasia in salivary glands. Oral Surg Oral Med Oral Pathol. 1990;69:53-67.

Darribère T, Skalski M, Cousin H, Gaultier A, Montmory C, Alfandary D. Integrins: regulators of embryogenesis. Biol Cell. 2000;92:5-25.

De Arcangelis A, Georges Labouesse E. Integrin and ECM functions: roles in vertebrate development. Trends Genet. 2000;16:389-95.

Denny PC, Ball WD, Redman RS. Salivary glands: a paradigm for diversity of gland development. Crit Rev Oral Biol Med. 1997;8:51-75. 
Drake CJ, Cheresh DA, Little CD. An antagonist of integrin alpha $v$ beta 3 prevents maturation of blood vessels during embryonic neovascularization. J Cell Sci. 1995; $108: 2655-61$

Dufour S, Duband JL, Humphies MJ, Obara M, Yamada KM, Thierry JP. Attachment, spreading and locomotion of avian neural crest cells are mediated by multiple adhesion sites on fibrinectin molecules. EMBO J. 1998;7:2661-71.

Ellis GL, Auclair PL. Tumors of salivary glands. Bethesda: Armed Forces Institute of Pathology - AFIP; 1996.(Atlas of tumor pathology, 17)

Ellis SJ, Tanentzapf G. Integrin-mediated adhesion and stem-cell-niche interactions. Cell Tissue Res. 2010;339:121-30.

Faraldo MM, Deugnier MA, Lukashev M, Thierry JP, Glukhova MA. Perturbation of $\beta 1$-integrin function alters the development of murine mammary gland. EMBO J. 1998;17:2139-47.

Faraldo MM, Deugnier MA, Thiery JP, Glukhova MA. Growth defects induced by perturbation of $\beta 1$-integrin function in the mammary gland epithelium result from a lack of MAPK activation via Shc and Akt pathways. EMBO Rep. 2001;2:431-7. 
Fässler R, Meyer M. Consequences of lack of $\beta 1$ integrin gene expression in mice. Gen Dev. 1995;9:1896-1908.

Fässler R, Rohwedel J, Maltsev V, Bloch W, Lentini S, Guan K, Gulberg D, Hescheler J, Addicks K, Wobus AM. Differentiation and integrity of cardiac muscle cells are impaired in the absence of $\beta 1$ integrin. J Cell Sci.1996;109:2989-99.

Franchi A, Santoro R, Paglierani M, Bondi R. Comparison of integrin $\alpha$ chain expression in benign and malignant salivary gland tumours. Oral Surg Oral Med Oral Pathol. 1997;83:588-95.

Gahmberg CG, Fagerholm SC, Nurmi SM, Chavakis T, Marchesan S, Grönholm M. Regulation of integrin activity and signaling. Biochim et Biophys Acta. 2009;1790:431-44.

Giancotti FG, Ruoslahti E. Integrin signaling. Science. 1999;285:1028-32.

Green LJ, Mould AP, Humphries MJ. The integrin $\beta$ subunit. Int J Biochem Cell Biol. 1998;30:179-84.

Grobstein C. Analysis in vitro of the early organization of the rudiment in the mouse submandibular gland. J Morphol. 1953a;93:19-43. 
Grobstein C. Morphogenetic interaction between embryonic mouse tissues separated by a membrane filter. Nature. 1953b;172:869-70.

Guan JL, Chen HC. Signal transduction in cell-matrix interactions. Int Rev Cytol. $1996 ; 168: 81-121$.

Gumbiner BM. Cell Adhesion: the molecular basis of tissue architecture and morphogenesis. Cell. 1996;84:345-57.

Gustafsson H, Kjörell U, Eriksson A, Virtanen I, Thornell L-E. Distribution of intermediate filament proteins in developing and adult salivary gland in man. Anat Embryol (Berl.) 1988;178:243-51.

Hammes HP, Brownlee M, Jonczyck A, Sutter A, Preissner KT. Subcutaneous injection of a cyclic peptide antagonist of vitronectin receptor-type integrins inhibits retinal neovascularization. Nat Med. 1996;2:529-33.

Hand AR. Salivary glands. In: Provenza, DV, Seibel W. Oral histology: inheritance and development. 2nd ed. Philadelphia: Lea \& Febiger; 1986.

Heino J. The collagen receptor integrins have distinct ligand recognition and signaling functions. Matrix Biol. 2000;19:319-23. 
Hemler ME. Integrin associated proteins. Curr Opin Cell Biol. 1998;10:578-85.

Hiatt JL, Sauk JJ. Embryology and anatomy of salivary glands. In: Ellis GL, Auclair PL,Gnepp DR. Surgical pathology of salivary glands. Philadelphia: Saunders. 1991.

Hynes RO. Integrins: a family of cell surface receptors. Cell. 1987;48:549-54.

Hynes RO. Integrins: versatility, modulation and signaling in cell adhesion. Cell. 1992; 69:11-25.

Hynes RO. Integrins: bidirectional, allosteric signalling machines. Cell. 2002;110:67387.

Jansen RP, Kiebler M. Intracellular RNA sorting, transport and localization. Nat Strut Mol Biol. 2005;12:826-9.

Jones JL, Walker RA. Integrins: a role as cell signalling molecules. Mol Pathol. 1999;52:208-13.

Juliano R. Cooperation between soluble factors and integrin-mediated cell anchorage in the control of cell growth and differentiation. Bioessays. 1996;18:9117. 
Kadoya $Y$, Yamanshina S. Distribuition of $\alpha 6$ integrin subunit in developing mouse submandibular gland. J Histochem Cytochem. 1993;41:1707-14.

Kadoya Y, Kadoya K, Durbeej M, Holmvall K, Sorokin L, Ekblom P: Antibodies against domain E3 of laminin-1 and integrin $\alpha 6$ subunit perturb branching epithelial morphogenesis of submandibular gland, but by different modes. J Cell Biol. 1995; 129:521-34

Kadoya Y, Mochizuki M, Nomizu M, Sorokin L, Yamashina S. Role for laminin-alpha5 chain LG4 module in epithelial branching morphogenesis. Dev Biol. 2003; 263:15364.

Kallman F, Grobstein C. Localization of glucosamine- incorporating materials at surfaces during salivary epithelial-mesenchimal interactions in vitro. Dev Biol.1966;14:52-67.

Kashimata M, Gresik EW. Contemporary approaches to the study of salivary gland morphogenesis. Eur J Morphol. 1996;34:143-7.

Kashimata M, Gresik EW. Epidermal growth factor system is a physiological regulator of development of the mouse fetal submandibular gland and regulates expression of the $\alpha 6$ integrin subunit. Dev Dyn. 1997;208:149-61. 
Klein RM. Development, structure and function of salivary glands. In: Avery, JK, editor. Oral development and histology. 2nd ed. New York: Thieme Medical Publishers; 1994.

Larsen M, Wei C, Yamada KM. Cell and fibronectin dynamics during branching morphogenesis. J Cell Sci. 2006;119:3376-84.

Larsen M, Artyn VV, Green JA, Yamada KM. The matrix reorganized: extracelular matrix remodeling and integrin signaling. Curr Opin Cell Biol. 2006;18:463-71.

Li N, Zhang Y, Naylor MJ, Schatzmann F, Maurer F, Wintermantel T, Schuetz G, Mueller $\mathrm{U}$, Streuli $\mathrm{CH}$, Hynes NE. Beta-1 integrins regulate mammary gland proliferation and maintain the integrity of mammary alveoli. EMBO $\mathrm{J}$. 2005;24:1942-53.

Loducca SV L, Raitz R, Araújo N S, Araújo V C. Polymorphous low grade adenocarcinoma and adenoid cystic carcinoma: distinct archirtetural composition revelead by collagen IV, laminin and their ligands ( $\alpha 2 \beta 1$ and $\alpha 3 \beta 1$ ) Histol. $2000 ; 37: 118-23$

Lourenço SV, Kapas S. Integrin expression in developing human salivary glands. Histochem Cell Biol. 2005;124:391-9. 
Lourenço SV, Lima, DMC. Pleomorphic adenoma and adenoid cystic carcinoma: in vitro study of the impact of TGF $\beta 1$ on the expression of integrins and cytoskeleton markers of cell differentiation. Int Exp Path. 2007; 88:191-8.

Luo B-H, Carman CV, Springer TA. Structural basis of integrin regulation and signaling. Annu Rev Immunol. 2007;25:619-47.

Maitra N, Flink IL, Bahl JJ, Morkin E. Expression of $\alpha$ and $\beta$ integrins during terminal differentiation of cardiomyocytes. Cardiovasc Res. 2000;47:715-25.

Mc Bride ML, Baillie J, Polland BJ. Growth parameters in normal fetuses. Teratology. 1984;29:185-91.

Meighan MC, Schwarzbauer JE. Temporal and spatial regulation of integrins during development. Curr Opin Cell Biol. 2008;20:520-4.

Menko AS, Kreidberg JA, Ryan TT, Van Bonckstaele E, Kukuruzinska MA. Loss of $\alpha 3 \beta 1$ integrin function results in an altered differentiation program in the mouse submandibular gland. Dev Dyn. 2001;220: 337-49.

Naylor MJ, Li N, Cheung J, Lowe ET, Lambert E, Marlow R, Wang P, Schatzmann F, Wintermante T, Schüetz G, Clarke AR, Mueller U, Hynes NE, Streuli CH. Ablation of Beta-1 integrin in mammary epithelium reveals a key role for integrin in glandular morphogenesis and differentiation. J Cell Biol . 2005;171:717-28. 
Raymond K, Deugnier M-A, Faraldo MM, Glukhova MA. Adhesion within the stem cell niches. Curr Opin Cell Biol. 2009;21:623-9.

Sakai T, Larsen M, Yamada KM. Fibronectin requirement in branching morphogenesis. Nature. 2003;423:876-81.

Sakakura T, Nishizuka Y, Dawe CJ. Mesenchyme-dependent morphogenesis and epithelium- specific cytodifferentiation in mouse mammary gland. Science. 1976;194:1439-41.

Sastry SK, Lakonishok M, Thomas DA, Muschler J, Horwitz AF. Integrin alpha subunit ratios, cytoplasmic domains and growth factor synergy regulate muscle proliferation and differentiation. J Cell Biol. 1996;133:169-84.

Spooner BS, Faubion JM. Collagen involvement in branching morphogenesis of embryonic lung and salivary gland.. Dev Biol. 1980;77:84-102.

Streuli $\mathrm{CH}$, Akhtar N. Signal co-operation between integrins and other receptor systems. Biochem J. 2009;418,491-506.

Sunardhi-Widyiaputra S, Van Damme B. Distribution of the VLA family of integrins in normal salivary gland and pleomorphic adenoma. Path Res Pract. 1994;190:600-08. 
Tanentzapf G, Devenport D, Godt D, Brown NH. Integrin-dependent anchoring of a stem-cell niche. Nat Cell Biol. 2007;9:1413-8.

Thiery J P. Cell adhesion in development: a complex signaling network. Curr Opin in Genet Dev. 2003,13:365-71.

Tonge $\mathrm{CH}$; Luke DA. Dental anatomy: the salivary glands. Dent Update. 1984;11:264,266,268-70.

Tucker AS. Salivary Gland Development. Semin Cell Dev Biol. 2007;18:237-44.

Varner JA, Cheresh DA. Integrins and cancer. Curr Opin Cell Biol. 1996;8:724-30.

Watt FM. Stem cell fate and patterning in mammalian epidermis. Cur Opin Gen Dev. 2001;11:410-7.

Watt FM. Role of integrins in regulating epidermal adhesion growth and differentiation. EMBO J. 2002;21:3919-26.

Watt FM, Hogan BL. Out of Eden: stem cells and their niches. Science. 2000;287:1427-30. 
Wehrle-Haller B, Imhof BA. Integrin-dependent pathologies. J Pathol. 2003; 200:481-7.

Yaku Y. Ultrastructural studies on development of human fetal salivary glands. Arch Histol Jnp. 1983;46:677-90.

Yilmaz M, Christofori G. EMT, the cytoskeleton, and cancer cell invasion. Cancer Metastasis Rev. 2009;28:15-33.

Zhu AJ, Haase I, Waat FM. Signaling via $\beta 1=$ integrins and mitogen-actived protein kinase determines human epidermal stem cell fate in vitro. Proc Natl Acad Sci USA. 1999;96:6728-33.

Zimmerman AA, Zeidestein S. The origen and distribuition of the labial and buccal glands in human fetus. J Dent Res. 1951;587-98. 


\title{
Expression of beta-1 integrin in human developing salivary glands and its parallel relation with maturation markers: In situ hybridisation and immunofluorescence study
}

\author{
Silvia Vanessa Lourenço ${ }^{a, b, c, *}$, Dirce Mary C. Lima ${ }^{b}$, Sabrina Hitomi Uyekita ${ }^{b}$, \\ Regina Schultz ${ }^{d}$, Thales de Brito ${ }^{b}$ \\ ${ }^{a}$ General Pathology Department, Dental School, University of São Paulo, Brazil \\ ${ }^{\mathrm{b}}$ Immunopathology Laboratory, Tropical Medicine Institute, University of São Paulo, Brazil \\ ${ }^{\mathrm{c}}$ Dermatology Department, Medical School, University of São Paulo, Brazil \\ ${ }^{d}$ Pathology Division, Hospital das Clínicas, Medical School, University of São Paulo, Brazil
}

\section{A R T I C L E I N F O}

\section{Article history:}

Accepted 14 May 2007

Keywords:

Salivary gland development

Human

Beta-1 integrin

\begin{abstract}
A B S T R A C T
Background and objective: Salivary gland development entails co-ordinated processes involving complex molecular interactions in which integrins have a fundamental role. The integrins are a family of heterodimeric transmembrane receptors comprising alpha and beta subunits that mediate intercellular and extracellular signals involved in the organisation of cells in tissues and organs during development. The beta- 1 integrin in particular have been implicated in proliferation and differentiation of cells involved in the development of epithelial tissues. To understand the role of beta-1 integrin in salivary gland development we have studied its expression in human foetal tissues.

Design: In situ hybridisation was used to compare the expression and localisation of integrin beta-1 with differentiation markers in developing human salivary glands obtained from foetuses of 8-24 weeks gestation.

Results: Integrin beta-1 first appeared during bud stage in a few cells and its distribution increased as salivary gland morphogenesis progressed. This increased pattern of beta-1 integrin expression was coincident with the appearance of the differentiation markers CK14, CK low MW and smooth-muscle actin.

Conclusions: The developmentally regulated expression of integrin beta- 1 in association with the establishment of a mature phenotype indicated by salivary gland tissue differentiation markers is suggestive of its role in salivary gland morphogenesis.
\end{abstract}

(C) 2007 Elsevier Ltd. All rights reserved.

\section{Introduction}

The position and shape of organs is determined by the coordinated activity of groups of primitive cells with each other and with surrounding cells. Cell shape changes, rearrange- ments and movements, often accompanied by regulated cell proliferation and/or cell death, are the primary mechanisms for generating the final shape of a functional mature organ. Although there is limited information available on how these cellular activities are co-ordinated, the expression of specific

\footnotetext{
* Corresponding author at: Instituto de Medicina Tropical de São Paulo, Av Dr Enéas de Carvalho Aguiar, 500, $2^{\circ}$ andar, CEP 05403-000, São Paulo, SP - Brazil. Tel.: +55 113061 7065; fax: +55 1130617065 .

E-mail address: sloducca@usp.br (S.V. Lourenço).

0003-9969/\$ - see front matter (C) 2007 Elsevier Ltd. All rights reserved.

doi:10.1016/j.archoralbio.2007.05.002
} 
cell surface ligands and receptors tightly linked in a complex web of signalling pathways that regulate cell division, migration and differentiation is essential feature of organ development. ${ }^{1}$

Similar to other organs the formation of the salivary gland involves co-ordination of morphogenetic mechanisms, including regulated cell shape changes and gene expression, and directed cell migration leading to a fully developed gland with important secretory functions. Morphologically, all salivary glands develop similarly, with formation starting with the proliferation of a solid cord of cells from the epithelium of the stomatodeum into the underlying ectomesenchyme. This cord of cells extends deeply into the ectomesenchyme, branches extensively, forming canals with secretory end pieces. ${ }^{2,3}$ The molecular mechanisms driving the development sequence of salivary gland appear to involve orchestration of different adhesion molecules and, in a series of studies, we have shown that interactions between cells and extracellular matrix are important in salivary gland biology and disease. ${ }^{4-6}$ These interactions are partially mediated by integrins, a family of heterodimeric transmembranic molecules composed by alpha and beta subunits. ${ }^{7}$ These heterodimers are divided into subfamilies on the basis of the beta subunit and those of the beta- 1 subfamily bind chiefly to components of the extracellular matrix. ${ }^{7,8}$ In addition to their cell attachment properties, integrins have been implicated in the maintenance of intercellular contacts as well as being involved in other dynamic biological mechanisms such as cell signalling and regulation of gene expression leading to proliferation and differentiation. ${ }^{7,9,10}$

Darribère et al. ${ }^{11}$ showed that integrins are fundamentally important in cellular differentiation involved in embryogenesis beginning at the fertilisation stage and through organogenesis. This knowledge has been applied to studies of the mammary and salivary gland epithelium and the key role of beta-1 integrin plays in glandular morphogenesis and differentiation verified.,12,13 In salivary glands, however, the expression of this adhesion molecule and its relationship to the glandular development sequence has not been elucidated. Given the importance of the beta- 1 integrin in cell adhesion and signalling in various tissues and organs and in developmental processes, the objective of this study was to evaluate the temporo-spatial expression of integrin beta-1 during human salivary gland development using in situ hybridisation. To determine the relationship of integrin beta-1 expression with salivary gland morphogenesis the study included the analysis of classical cytoskeletal markers of salivary gland structures.

\section{Material and methods}

Specimens from the oral cavity of 26 human foetuses at 8-24 weeks of gestation were obtained from the Medical School of the University of São Paulo and in accordance with authorisation of the Ethical Committee of this institution. The specimens were collected from different oral sites, including the buccal mucosa, tongue, mandible and hard palate. All specimens were fixed in buffered formalin and embedded in paraffin. Sections of the specimens were stained with haematoxylin and eosin to check for the presence of salivary glands and to study their morphology and determine their developmental phase. Those presenting developing major or minor salivary glands were selected for the present analysis. Three specimens of adult, fully developed salivary gland were also included in the study for comparative analysis of the expression patterns of integrin beta-1.

\section{In situ hybridisation}

To assess the expression of integrin beta- 1 in the specimens selected, an oligonucleotide probe was synthesised to detect beta-1 integrin based on the published sequence of this molecule. ${ }^{13}$ Probe $\left(5^{\prime}-3^{\prime}\right.$ AAA TTC CTG AGC TTA GCT GGT GTT GTG CTA ATG TSS GGC ATC ACA GTC TTT TCC ACA AAT) (GenBank accession number X07979) is a sense biotin-labelled probe complementary to the sequences used for PCR. As a negative control, a biotin-labelled scrambled probe was employed following the same protocol $\left(5^{\prime}-3^{\prime}\right.$ CCG TGT GGG ACG GAA CTT ACG CGA TSS CGG CAG ACT AAT AGC AGT CGG AAG GTC CAT). For ISH, $5 \mu \mathrm{m}$ sections were de-paraffinised, re-hydrated through a graded series of ethanol, and washed with water treated with $0.1 \%$ diethylpyrocarbonate (DEPC) for $5 \mathrm{~min}$. The sections were incubated with $25 \mu \mathrm{g} / \mathrm{mL}$ of proteinase K (Sigma, St. Louis, MO, USA) in PBS for $10 \mathrm{~min}$ at $37^{\circ} \mathrm{C}$ and then permeabilised with $2 \%$ Triton in Tris- $\mathrm{HCl}$ $10 \mathrm{mM}$, at room temperature. These sections were rinsed with $\mathrm{DEPC}$ for $10 \mathrm{~min}$ and incubated at $95^{\circ} \mathrm{C}$ for $7 \mathrm{~min}$ in hybridisation buffer (50\% dextran sulphate, $20 \times$ SSC, $50 \times$ Denhart's, $10 \mathrm{mg} / \mathrm{mL}$ of salmon sperm DNA, $10 \mathrm{mg} / \mathrm{mL}$ of inorganic pyrophosphate in $1 \mathrm{M}$ Tris buffer, $\mathrm{pH} 7.4$, deionised formamide, and DEPC). The sections were then incubated overnight at $55^{\circ} \mathrm{C}$, with the corresponding probe, at a concentration of $1 \mu \mathrm{M}$ in hybridisation buffer. After incubation, the sections were washed in Tris- $\mathrm{HCl}, \mathrm{pH} 7.4$, at $42^{\circ} \mathrm{C}$ for $10 \mathrm{~min}$ and further washed with water five times for $5 \mathrm{~min}$. The slides containing the tissue sections were then incubated with the subsequent steps of the kit Gen point (Dako Cytomation). The reactions were finally developed with the chromogen 3'3 diaminobenzidine tetrachloride (DAB) (Sigma, St. Louis, MO 63178, USA). The specimens were then lightly counterstained with Carazzi's haematoxylin, dehydrated and mounted with a glass coverslip and a xylene-based mounting reagent. The results were analysed under an optical microscope equipped with a digital camera for image acquisition.

\section{Immunofluorescence}

Serial sections $(3 \mathrm{~mm})$ of the formalin-fixed, paraffin embedded developing salivary glands specimens were rehydrated and incubated with $1 \%$ bovine serum albumin (BSA) and $5 \%$ foetal calf serum (FCS) in Tris- $\mathrm{HCl} \mathrm{pH} 7.4$ for $60 \mathrm{~min}$ at room temperature to suppress non-specific binding of subsequent reagents. The double labelling immunofluorescence reactions were performed in two steps. First, the sections were incubated with the primary antibody, followed by incubation with sheep anti-mouse FITC-conjugated immunoglobulin (Novocastra) (diluted 1:100 in BSA-PBS). Incubation with the 
Table 1 - Primary serum, clones, source, and details of working protocol

\begin{tabular}{|c|c|c|c|c|c|}
\hline Primary serum & Clone & Specificity & Source & Antigen retrieval & $\begin{array}{l}\text { Working } \\
\text { dilution }\end{array}$ \\
\hline CK14 & LL002 & Epitope C-terminal of human CK14, isotype IgG 3 & Neomarker & Citrate buffer pH 6.0 & 1:50 \\
\hline CK low-MW & 35beta H11 & Epitope not specified, isotype IgM kappa & DAKO & Citrate buffer $\mathrm{pH} 6.0$ & 1:50 \\
\hline SMA & 1A4 & Epitope $\mathrm{N}$-terminal, isotype IgG2a kappa & DAKO & Citrate buffer pH 6.0 & $1: 50$ \\
\hline
\end{tabular}
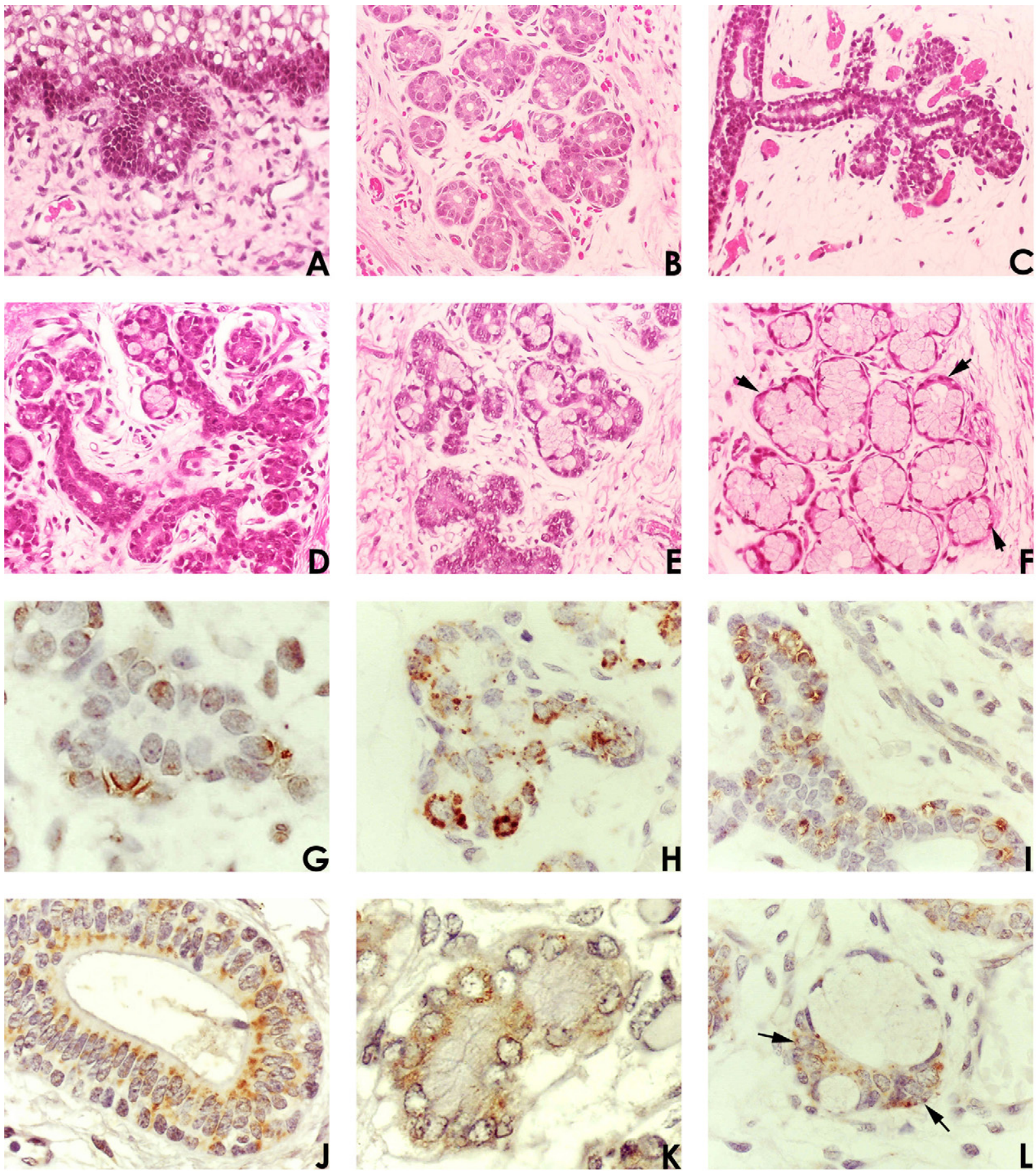

Fig. 1 - (A) Initial phase of salivary gland development-epithelial bud composed of eosinophilic cuboidal cells, invaginating into the mesenchyme from the basal layer of the covering mucosal epithelium (H/E, original magnification $\times 400)$. (B) Proliferation/canalisation phase of salivary gland development-presence of epithelial nests with formation of small lumen in the center (H/E, original magnification $\times 250)$. (C) Branching/arborisation phase: complex ductal system well formed and canalised $(H / E$, original magnification $\times 250)$. (D and $E$ ) Initial phase of acinar differentiation-presence of rudimentary acinic structures (end pieces) in the terminal portion of the branching ductal system (H/E $\times 250)$. (F) Advanced acinar 
second primary antibody was performed, followed by incubation with goat anti-mouse IgG labelled with red fluorescent Alexa 594 (Molecular Probes) at a concentration of 1:100. The details of the monoclonal primary antibodies used, their source, and working dilutions are described in Table 1. All steps were preceded by two incubations with Tris- $\mathrm{HCl}$ pH 7.4 for $5 \mathrm{~min}$ at room temperature. The sections were then air dried and mounted with Vecta Shield. The results were analysed and photographed using a Zeiss microscope equipped with epi-illumination and a digital camera with filters for fluorescein and rodamine. Negative controls were treated as above, but a solution of $1 \%$ BSA in Tris- $\mathrm{HCl}$ pH 7.4 replaced the primary antibody. Specimens incubated with normal serum were used as additional negative controls. Internal positive controls such as basal layer of epithelium were present.

\section{Results}

The specimens studied were of the major and minor human salivary glands at various stages of development, comprising bud, proliferation, canalisation, branching and cytodifferentiation (Fig. 1A-F).

\subsection{In situ hybridisation (ISH) of human embryonic salivary glands (Fig. 1G-L)}

Salivary glands at the bud stage of development were scarce and only rare cells expressed integrin beta-1, which was located around the cell membrane at their contact with the stroma and, sometimes, as cytoplasmic dots. During the initial steps of proliferation and canalisation stage, a few developing salivary gland ducts could be observed. Beta-1 integrin was present in rare cells, showing a ring-like pattern seen in the basal pole of some ductal cells or around the cell membrane in an intercellular position. When canalisation was more evident, an increased number of ductal cells expressed the beta-1 integrin in a similar pattern as described above and in a punctate pattern around the cell membrane. At the stage of branching and initial cytodifferentiation, beta-1 integrin was present in a greater number of cells, usually as bipolar dots in the cytoplasm and membrane of epithelial cells of the canalised ducts and around the cell membrane. Expression of integrin beta-1 was also seen at the basolateral portion of a few rudimentary developing acinic cells. Expression of this integrin was seen along the more mature ducts, usually showing a bipolar distribution and at the apical pole of luminal cells.
Cytoplasmic signal was increasingly detected as differentiation of salivary gland progressed.

At a subsequent differentiation stage (advanced cytodifferentiation), beta-1 integrin was present at the basolateral portion of some acinic structures and more abundantly in the cells along the ductal system, more frequently as cytoplasmic signals. The ring-like pattern of expression was still observed in a few ductal cells. Finally, adult normal salivary glands, used as controls for the reactions showed expression of integrin beta-1 along all the ductal system. Intercalated ducts showed signal for beta-1 integrin in a cell-membrane bipolar pattern. The other segments of salivary gland duct presented expression of integrin beta-1 both in a cytoplasmic and membrane location. Negative controls did not show any signal.

\subsection{Immunofluorescence of human embryonic salivary glands}

At the bud stage of salivary gland development, only a few cells were weakly positive for CK14 (Fig. 2A). During the proliferation and canalisation stage, a few developing salivary gland ducts were observed. In these phases, CK14 and low molecular weight cytokeratin (CK LMW/35beta H11) were present in the ductal epithelial cells and smooth-muscle actin (SMA) was only found in rare cells (Fig. 2B, C, G, H).

At the stage of branching and initial cytodifferentiation, ductal cells were positive for CK 14 (Fig. 2D). Luminal cells of the developing ductal system were positive for CK LMW/ 35beta H11. Smooth-muscle actin was detected in cells of the terminal portion of the ductal system and in cells that surrounded the rudimentary acinic lobules (Fig. 2 I and J). At late acinar cytodifferentiation, CK14 was detected in the cytoplasm of basal cells of the ductal system. Myoepithelial cells were positive for CK14 and SMA. CK LMW/35beta H11 was seen on luminal cells of the ductal system (Fig. 2E, F, K and L).

\section{Discussion}

Our results demonstrated that the expression of beta-1 integrin in different patterns along the process of differentiation of human salivary glands increased as development progressed, suggesting that it may be an indicator of salivary gland maturation. The demonstration of integrin beta-1 mRNA using the very sensitive technique of in situ hybridisation complemented the results of our previous work in which the beta-1 integrin protein was demonstrated the using

differentiation: mucous acinar lobules well developed, composed by pyramidal cells with large and clear cytoplasm and surrounded by thin elongated myoepithelial cells (arrow) (H/E original $\times 400)$. (G) Initial phase of proliferation/canalisation: expression of beta-1 integrin concentrated of the baso-lateral portion of the membrane in a few epithelial cells (in situ hybridisation, original magnification $\times 400)$. ( $H$ and I) Canalisation/arborisation of the developing ductal system: increased expression of beta-1 integrin on the membrane of ductal cells. Note in $(\mathrm{H})$, the marked expression of the molecule in a dotted pattern surrounding the entire cell membrane (in situ hybridisation, original magnification $\times 250$ ). (J) Fully developed excretory duct: expression of beta-1 integrin in a bipolar pattern in the various layers of ductal cells (in situ hybridisation, original magnification $\times 250)$. (K) Initial phase of acinar differentiation: expression of beta-1 integrin around the cell membrane and in peri-nuclear position of the immature acinar cells (in situ hybridisation, original magnification $\times 400$ ). (L) Fully developed acinar lobule: expression of beta-1 integrin concentrated in the cells of the intercalary-acinar unit (arrows) (in situ hybridisation, original magnification $\times 400$ ). 

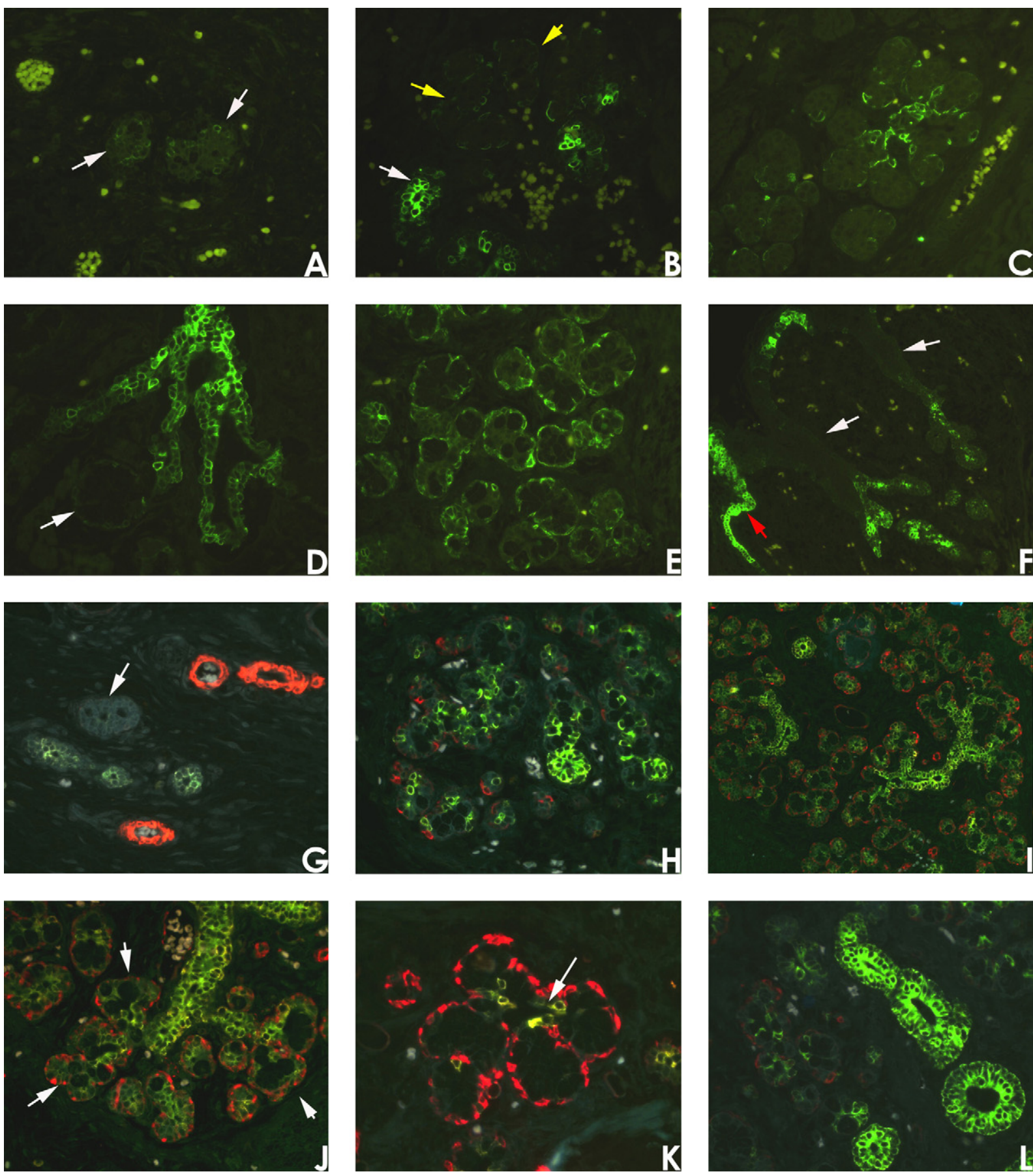

Fig. 2 - (A) Bud stage of salivary gland development: weak expression of CK14 in is detected in the cytoplasm of a few epithelial cells of the incipient gland islets (arrows) (original magnification $\times 400)$. (B and C) Proliferation/canalisation phase: epithelial structures exhibiting strong expression of CK14 in the cytoplasm of ductal cells. Observe in (C) a well-formed and canalised salivary gland structure (arrow). Other further developed structures start to present weak positivity surrounding epithelial lobules, probably representing the initial maturation of myoepithelial cells (yellow arrow) (original magnification $\times 250$ (B) and $\times 400$ (C)). (D) Branching phase: in this stage presence of CK 14 is observed in a greater number of cells of the ductal system of the developing gland (original magnification $\times 400$ ). (E) Acinar differentiation: acinar lobules that present immunoexpression of CK14 in myoepithelial cells surrounding the acinar lobules (original magnification $\times 400$ ). (F) Welldeveloped excretory ducts: strong expression of CK14 is observed in the cytoplasm of basal keratinocytes of the lining mucosa epithelium (red arrow) and in cytoplasm the well-formed ductal system of the salivary gland. Note that the portion of the duct next to the covering epithelium is still negative for this marker (white arrow) (original magnification $\times 400)$. (G) Initial phase of proliferation/canalisation: a few canalising epithelial lobules of developing salivary glands present weak cytoplasmic positivity for CK LMW/35beta H11 (green). SMA (red) is only detected in blood vessels walls in this phase. Note the presence of more rudimentary salivary gland lobules still negative for CK LMW/35beta H11 (arrow) (original 
immunohistochemistry. ${ }^{6}$ In this study, double labelling immunofluorescence was used to identify and highlight the presence of classical cytoskeletal markers of salivary gland differentiation.

To date, little is known of the molecular mechanisms that regulate the development of the human salivary gland. As with other glands and tissues, it is very likely that development is co-ordinated via several integrated events affecting proliferation, morphogenesis and cell-substratum interactions. These events are tightly regulated both temporally and spatially. ${ }^{14}$ Differentiation of salivary glands begins around week 6 of foetal development when specific oral epithelium cells undergo organised, co-ordinated growth that is based on epithelio-mesenchymal interactions, leading to morphogenesis and cytodifferentiation. ${ }^{15,16}$ Integrins appear to be key molecules involved in these interactions and perturbations of their expression can lead to impaired glandular form and function. For example, Menko et al. ${ }^{17}$ have demonstrated that the absence of the integrin dimer alpha3beta1 affects multiple components of adhesive complexes and their associated signalling pathways in salivary glands. These include profound alterations in the signalling cascade that involves Cdc42 and RhoA, two Rho GTPases that regulate the organisation of the actin cytoskeleton. ${ }^{17}$

The role of beta-1 integrin has been investigated in other tissues and its importance in their developmental processes is being established. In mammary glands, which display a similar morphology to the salivary glands, perturbation of beta-1 integrin results in impaired development and differentiation of the secretory epithelium. ${ }^{18}$ Supporting this, Naylor et al. ${ }^{13}$ has shown that the disturbance of mammary gland lobular development in mice is due to the lack of beta-1 integrin which manifest as defects in epithelial proliferation triggered by the absence of this molecule.

During the initial stages of human salivary gland morphogenesis - bud stage - beta-1 integrin, was present in scattered cells and as differentiation progressed, it was expressed in an increasing number of cells. These results suggest that beta-1 integrin is important in the initial phase of salivary gland development, when interactions between the bud epithelial cells and their newly formed extracellular environment occur. In a parallel analysis, double staining immunofluorescence showed none of the classical cytoskeletal differentiation markers, indicating that the glandular tissue is very immature at this phase. This result is in accordance with a previous report by Martins et al. ${ }^{19}$ who did not find any markers of differentiation in the very early stage of salivary gland development. With further differentiation, expression of beta-1 integrin increases, creating new connections likely to be important for subsequent steps in gland development.

In early stages of salivary gland canalisation, beta-1 integrin was expressed in a peculiar ring-like pattern in some cells of the developing ductal network. Analogous to the results of other authors, whose studies have implicated beta-1 integrin as a marker of the stem cell niche in mammary gland and skin, ${ }^{20}$ it is conceivable that these cells may represent very primitive, pluripotent cells of the salivary gland tissue. Additionally, extracellular matrix proteins may modulate the expression and activation of beta-1 integrins in these cells, and local variation in the composition of basement membrane during the gland development might play a role in establishing and maintaining their distribution. ${ }^{20}$

At the canalisation stage when beta-1 integrin is also well identified in cells of the ductal network, more differentiation markers are detected in the developing salivary glands, which stain for CK14 and CK LMW/35beta H11, indicating that cytodifferentiation has progressed. Integrin receptors and ligands have been shown to activate signalling pathways involving mitogen-activated protein kinases, tyrosine kinases or GTP-binding proteins. These are thought to affect cell cytoskeleton and proliferative responses that are required during organ development. ${ }^{21}$ However, this relationship has yet to be shown at the molecular level in human salivary gland development. On the basis of the present morphological evidence, functional studies, possibly using tissue culture or animal models are imperative for substantiating the suggestions made from these morphological observations.

In advanced canalisation stage of salivary gland development, beta-1 integrin was present in a greater number of cells, with signals detected either on the membrane or in the cytoplasm. The differential mRNA localisation may reflect a novel type of post-transcriptional control involved in many cellular processes, including the regulation of cellular asymmetry required for creating and maintaining cell polarity, which is important for cellular differentiation during development. Thus, site-specific localisation of mRNA in the cytoplasm may provide an important mechanism whereby specialised proteins can be expressed at discrete sites within the cell. ${ }^{21,22}$ In developing salivary glands, the presence of beta- 1 integrin at these locations may be important for the protein transcription locally, which later may determine cell polarity to prepare glandular structures for their secretory functions. Also, some cells still retained the ring-like pattern of beta-1 integrin expression. Other cells of the branched ductal system expressed beta- 1 integrin at the basolateral surface of the membrane. This varied morphological pattern of expression suggests that integrins might play diverse roles in the process of salivary

magnification $\times 400)$. (H and I) Canalisation/branching phase: strong expression of CK LMW/35beta H11 (green) is observed in cytoplasm of epithelial cells of the branched ductal system. Initial expression of SMA (red) is seen in the cytoplasm of myoepithelial cells surrounding the terminal portion of the branching ducts (original magnification $\times 400$ and $\times 250$, respectively). (J) Initial phase of acinar differentiation: expression of CK LMW/35beta H11 (green) is detected in the cytoplasm of epithelial cells of the ductal system. Smooth muscle actin (red) is present in the cytoplasm of myoepithelial cells surrounding the incipient acinic structures (arrows) (original magnification $\times 400)$. (K) Well-formed acinar lobules: strong expression of SMA (red) is observed in the thin cytoplasm elongated myoepithelial cells around the well-developed acinar lobules. A few cells are positive for CK LMW/35beta H11 (green), probably representing intercalated duct cells (arrow) (original magnification $\times 600$ ). (L) Well-developed ductal system: epithelial cells showing cytoplasmic strong positivity for CK LMW/35beta H11 (green) (original magnification $\times 400)$. 
gland development, either in the differentiation and maintenance of the salivary gland phenotype, mediating a close relationship between gland parenchyma and extracellular matrix and also being associated with glandular functions, as reported by others (see ${ }^{1}$ for review). This pattern of distribution is thought to be involved in the stable attachment of stationary epithelial cells to the matrix and in the maintenance of cell-cell interactions, ${ }^{23}$ suggesting that integrin beta- 1 expression might be a cell-membrane indicator of the evolutionary steps of salivary gland morphogenesis. At this time, the phenotype of cells that comprise the main structure of the developing gland is well defined by the expression of CK14, CK LMW/35beta H11 and SMA, which provide a parallel demonstration of glandular maturation.

In late stages of salivary gland development, indicated by branching and cytodifferentiation of acinar cells, beta-1 integrin mimics the patterns seen in the normal adult salivary gland structures. Thus, beta-1 integrin showed a cytoplasmic expression in the apical pole of luminal cells, as well as basolateral portion of ductal cells. This phenomenon may account for the secretory functions of salivary glands and is similar to what has been observed in other secretory organs such as stomach and breast. ${ }^{23-25}$ Cytoskeletal markers of salivary gland differentiation are present in this phase of the gland development in specific patterns, close to those classically described in adult glands. ${ }^{19,26,27}$ The increase in the expression of beta-1 integrin and markers of differentiation as salivary gland development and differentiation confirms the requirement for this integrin in maintaining tissue-specific functions. For instance, being implicated in the control, of mammary gland differentiation. . $^{13,28}$

The present research has shown morphological evidence that integrins may be cell membrane indicators of human salivary gland differentiation with a parallel relation with the establishment of a salivary gland mature phenotype disclosed by the classical cytoskeletal differentiation markers. The integrins are developmentally regulated and appear to be sensitive to changes in the gland extracellular microenvironment as morphogenesis progresses. These morphological data provide a cornerstone for future functional and molecular studies that are at present being carried out in our laboratory.

\section{Acknowledgements}

Supported by FAPESP grants 02/02676-7 and 03/00450-4 and British Council Academic Link SPA/881/155. Division of Pathology of the Hospital da Clínicas, Medical School, University of São Paulo, for supplying the foetal tissue used in this work. All experiments carried out in this work comply with the laws of the Ethical Committee of the Medical School of the University of São Paulo.

\section{R E F E R E N C E S}

1. Thiery JP. Cell Adhesion in development: a complex signalling network. Curr Opin Gen Dev 2003;13:365-71.

2. Dale AC. Salivary gland. In: Ten Cate AR, editor. Oral histology. 4th ed. St. Louis: Mosby; 1994. p. 312-33.
3. Klein RM. Development, structure and function of salivary glands. In: Avery JK, editor. Oral development and histology. 2nd ed. New York: Thieme; 1994. p. 352-79.

4. Araújo VC, Loducca SVL, Sousa SOM, Williams DM, Araújo NS. The cribriform features of adenoid cystic carcinoma and polymorphous low-grade adenocarcinoma: cytokeratins and integrins expression. Ann Diagn Pathol 2001;5(6):330-4.

5. Loducca SVL, Raitz R, Araújo NS, Araújo VC. Polymorphous low-grade adenocarcinoma and adenoid cystic carcinoma: distinct architectural composition revealed by collagen IV, laminin and their integrin ligands $\alpha 2 \beta 1$ and $\alpha 3 \beta 1$. Histopathology 2000;37:118-23.

6. Lourenço SV, Kapas S. Integrin expression in developing salivary glands. Histochem Cell Biol 2005;124:391-9.

7. Hynes RO. Integrins: versatility, modulation, and signalling in cell adhesion. Cell 1992;69:11-25.

8. Hynes RO. Integrins: a family of cell surface receptors. Cell 1987;48:549-54.

9. Ruoslahti E, Reed JC. Anchorage dependence, integrins, and apoptosis. Cell 1994;77:477-8.

10. Varner JA, Cheresh DA. Integrins and cancer. Curr Opin Cell Biol 1996;8:724-30.

11. Darribère $T$, Skalski $M$, Cousin $H$, Gaultier $A$, Montmory $C$, Alfandari D. Integrins: regulator of embryogenesis. Biol Cell 2000;92:5-25.

12. Beauvais-Joneau A, Thierry JP. Multiple roles for integrins during development. Biol Cell 1997;89:5-11.

13. Naylor MJ, Li N, Cheung J, Lowe ET, Lambert E, Marlow R, et al. Ablation of $\beta 1$ integrin in mammary epithelium reveals a key role for integrin in glandular morphogenesis and differentiation. J Cell Biol 2005;171:717-28.

14. Cutler LS, Functional differentiation of salivary glands.Forte $\mathrm{J}$, editor. Handbook of physiology salivary pancreatic gastric and hepatobiliary secretion, vol. 3. New York: Am Physiological Soc Press; 1989. p. 93-105.

15. Cutler LS. The role of extracellular matrix in the morphogenesis and differentiation of salivary glands. Adv Dental Res 1990;4:27-33.

16. Kashimata M, Gresik EW. Contemporary approaches to the study of salivary gland morphogenesis. Eur J Morphol 1996;34:143-7.

17. Menko AS, Kreidberg JA, Ryan TT, Van Bockstaele E. Loss of alpha3beta1 integrin function results in an altered differentiation program in the mouse submandibular gland. Dev Dyn 2001;220(4):337-49.

18. Faraldo MM, Deugnier MA, Lukashev M, Thierry JP, Glukhova MA. Perturbation of beta 1-integrin function alters the development of murine mammary gland. EMBO J 1998;17:2139-47.

19. Martins MD, Araújo VC, Raitz R, Araújo NS. Expression of cytoskeletal proteins in developing human minor salivary glands. Eur J Oral Sci 2002;110:316-32120.

20. Watt FM, Hogan LM. Out of Eden: stem cells and their niches. Science 2000;287:1427-30.

21. Jansen RP, Kiebler M. Intracellular RNA sorting, transport and localization. Nat Strut Mol Biol 2005;12:826-9.

22. Czaplinski K, Singer RH. Pathways for mRNA localization in the cytoplasm. Trends Biochem Sci 2006;31:687-93.

23. Coraux C, Zahm JM, Puchelle E, Gaillard D. Beta-1 integrins are involved in migration of human fetal tracheal epithelial cells and tubular morphogenesis. Am J Pathol 2000;279: 224-34.

24. Chénard M, Barque JR, Chailler P, Trembaly E, Beaulieu JF, Ménard D. Expression of integrin subunits correlates with differentiation of epithelial cell lineages in developing human salivary human gastric mucosa. Anat Embryol 2000;202:223-33.

25. Li N, Zhang Y, Naylor MJ, Schatzmann F, Maurer F, Wintermantel $\mathrm{T}$, et al. Beta-1 integrins regulate mammary 
gland proliferation and maintain the integrity of mammary alveoli. EMBO J 2005;24:1942-53.

26. Draeger A, Nathrath WB, Lane EB, Sundstrom BE, Stigbrand TI. Cytokeratins, smooth muscle actin and vimentina in human normal salivary gland and pleomorphic adenomas. Immunohistochemical studies with particular reference to myoepithelial and basal cells. APMIS 1991;99(5):405-15.
27. Zarbo RJ, Bacchi CE, Gown AM. Muscle-specific protein expression in normal salivary glands and pleomorphic adenomas: an immunocytochemical study with biochemical confirmation. Mod Pathol 1991;4(5):621-6.

28. Fuchs E, Cleveland DW. A structural scaffolding of intermediate filaments in health and disease. Science 1998;279(5350):514-9. 